\title{
THE ROLE OF THE STATES IN CORPORATE REGULATION AND INVESTOR PROTECTION
}

\author{
RichaRd W. JENNIngs*
}

\section{INTRODUCTION}

The purpose of this paper is to explore some of the current issues and trends in state corporation and securities legislation. There is a wide difference of opinion as to whether state incorporation statutes should be primarily enabling acts, with a minimum of regulation, or whether they should include additional protective provisions designed to establish more adequate safeguards for shareholders and creditors. A similar controversy exists in the field of state securities regulation, where varying approaches range from little or no regulation to a maximum of it.

The competition among the states for corporate charters has been a dominant factor in bringing about lax corporation statutes, although from time to time, individual states have attempted to resist sach pressures. More recently, the Model Business Corporation Act, ${ }^{1}$ sponsored and drafted by the American Bar Association Committee on Corporate Laws, has exerted a considerable influence in several American jurisdictions which have undertaken a revision of their corporation statutes. $^{2}$

In the field of state securities regulation, the Harvard Law School Study of State Securities Regulation, under the direction of Professor Louis Loss and Edward Cowett, has culminated in the "promulgation" of a new Uniform State Securities Act which has as its purpose the promotion of uniformity in this area of the law. ${ }^{3}$ This new Uniform Act has received the approval of the National Conference of Commissioners on Uniform State Laws ${ }^{4}$ and the endorsement of the House of Dele-

- A.B. 1927, Park College; A.M. I934, University of Pennsylvania; LL.B. 1939, University of California, Berkeley. Member of California bar; James W. and Isabel Coffroth Professor of Law, University of California, Berkeley. Co-author [with Henry W. Ballantine and Norman D. Lattin], CAsEs AND Materials on Corporations (1953). Editor, P-H Students' Corporation Law Service.

${ }^{2}$ Committee on Corporate laws, Amierican Bar Association, Model Business Corporation Act (1953); id., Revisions and Optional Sections (1955); id., Addendum of Revisions, Alternative Provisions and Optional Sections (1957). These will hereafter be referred to as the 1953, 1955, and 1957 revisions.

${ }^{3}$ Included are Wisconsin (1951), Oregon (1953), Texas (1955), Virginia (1956), North Dakota (1957), Alaska (1957), and Colorado (1958). The Model Act was also used by Congress in enacting a corporation law for the District of Columbia. See Campbell, The Model Bussiness Corporation Act, Business Lawyer, July x956, pp. 98, x06-07.

${ }^{3}$ Louis Loss and Edward Cowett, A Proposed Uniform Securities Act-Final Draft and ComMENTARY (1956). This temporary edition has since been superseded by a treatise on the state blue-sky laws which also includes the new Uniform Securities Act with Official Comments and Draftsmen's Com. mentary. Louis Loss and Edward CowetT, Blue Sky Law (1958). The Uniform Act also appears in 9 C U.L.A. 84 (1957).

"Nat'l Conference of Comin'rs on Uniform State Laws, Handbook 134-35 (r956). 
gates and the Board of Governors of the American Bar Association. ${ }^{5}$ It has been less warmly received by the National Association of Securities Administrators (since renamed North American Securities Administrators), which, after having given a guarded approval of the Act "insofar as may be practicable to promote uniformity in legislation," has made clear that this gesture "was not intended to and did not approve or recommend the Uniform Act for adoption in any state."

It seems particularly appropriate in this symposium to pinpoint some of the difficulties in formulating an effective legislative program at the state level; to take inventory of our past experience; and to evaluate these latest efforts to provide guidance for the formulation of state legislation. In the last connection, special attention will be given a determination of the extent to which the new proposals will weaken or strengthen corporation legislation in our federal system.

\section{Corporate Control and the Federal System}

\section{A. The Problem of Charter-Mongering: Corporate Homes Away from Home ${ }^{7}$}

The regulation of corporate enterprise in the United States so as to afford adequate protection for investors poses many complexities. Despite the tremendous growth in the number and size of corporation, the interstate character of the economy, and existing federal securities legislation, the states play a crucial part in the development of effective techniques for the prevention of abuse of power by management and majority shareholders and for the safeguarding of rights of minority shareholders and other investors.

The power to incorporate is conferred by the states under general incorporation laws. These statutes prescribe the corporate structure and the relationships between the management and the shareholders, between the majority and the minority shareholders, and between classes of shareholders. The extent to which the internal affairs of corporations are regulated varies markedly from state to state. The incorporation statutes of the more "liberal" states are essentially enabling acts, which contain many loopholes for an irresponsible management and a minimum of protective provisions in the interest of shareholders. Their general laissez-faire character is, in part, a product of our federal system, which permits the free choice of a state of incorporation, regardless of where the business is to be conducted. ${ }^{8}$

${ }^{5}$ 8x A.B.A. Rep. 145 (1956).

- Nat'l Ass'n of Securities Adm'rs, Proceedings ilz (1956); N. Am. Securities Adm'rs, ProceedINGS 64-66 (1957).

7 The phrase is suggested by Marias, Liechtenstein, A Corporate Home Away from Home, 12 Bus1NESS LAWXER 405 (I957).

${ }^{8}$ Compare the Canadian system. The British North America Act, x867, 30 \& 31 Vrcr. c. $3, \$ 92$, delegates to the provinces exclusive power to incorporate companies with "provincial objects." The residual authority to incorporate all other companies rests with the dominion government. Dominion companies have a federal right to carry on business in every province. Although a province may requirc such companies to register with its government, compliance cannot be made a condition precedent to doing business within its territory. They may also enforce general regulatory laws against a dominion company, including tax and securities laws. A province cannot confer upon local corporations power to do business elsewhere, but it can confer upon its companies the capacity to accept extraprovincial 
These "liberal" state statutes date from the latter part of the last century, when certain states began to revamp their corporation statutes so as to give the widest latitude to corporate promoters and managers, with a view to inducing out-of-state businesses to incorporate in the state and escape restrictive legislation at the business home. Vast numbers of corporations engaged in interstate business took shelter in these corporate havens, even where no business was to be conducted in the state of incorporation. Moreover, "pseudo foreign corporations" were formed by incorporating a purely intrastate business in a charter-mongering state solely for the purpose of becoming liberated from effective regulation in the home state. ${ }^{10}$ In the words of Mr. Justice Brandeis: $:^{11}$

[L]ocal restriction seemed worse than futile. Lesser States, eager for revenue derived from the traffic in charters, had removed safeguards from their own incorporation laws. Companies were early formed to provide charters for corporations in states where the cost was lowest and the laws least restrictive. The States joined in advertising their wares. The race was not one of diligence but of laxity ... and the great industrial States yielded in order not to lose wholly the prospect of the revenue and the control incident to domestic incorporation.

Where individual states have sought to resist these pressures, the "pseudo-foreign corporation" has become the problem-child of all efforts at effective regulation.

A partial answer to the problem of charter-mongering might have been found in the enactment of a federal incorporation statute applicable to some or all corporations engaged in interstate commerce, possibly with a limitation based upon the amount

powers. Bonanza Creek Gold Mining Company, Itd. v. Rex [1916] I A.C. 566. See generally Cornelius A. Masten and William K. Fraser, Company Law of Canada 24-28 (4th ed. I94r).

- This movement, although it has an earlier history, received an added impetus with the New Jersey, amendments of $x 888$, which generally authorized corporate holding companies. N.J. Laws 1888 , c. 269 , at 385 . That same state enacted, in 1896 , the first of the "liberal" general incorporation statutes, eliminating any restrictions on duration of existence, contributed capital, or types of enterprises. The Delaware incorporation statute of 1899 was modeled after the New Jersey original, but it emerged in many respects with even more advantages for management. Charter-mongering statutes were later enacted by Maine, Maryland, Nevada, and South Dakota, in some cases as defensive measures to retain corporate business rather than from conviction. See Compton, Early History of Stock Ownership by Corporations, 9 Geo. Wastr. L. Rev. 125 (1940); Wright and Baughman, Past and Present Trends in Corporation Law: Is Florida in Step?, 2 Miami L.Q. 69, 86 (1947); James C. Bonbright and Gardiner C. Means, The Hording Company 55-64 (1932); Louis K. Liggett Co. v. Lee, 288 U.S. 517, 557-64 (1933). For current discussion, see Bedingfield, They Want to Get Away from It All, N.Y. Times, April 2I, 1957, 3, p. I.

${ }_{10}^{10}$ See Latty, Psetsdo-Foreign Corporations, 65 Yale L.J. 137 (1955). In the international field, inducements to migrate as a means of escape from restrictive tax, labor, or other legislation or to conceal ownership are also offered. In New York and Zürich, organizations exist with facilities to activate $x$ Liberian corporation within forty-eight hours; if greater speed is needed, these correspondents have available, for a fee, corporate shells, already processed in Liberia, and ready for immediate delivery. See Rudick, Foreign Domiciles for Corporations-Advantages Offered by the Republic of Liberia, I2 Business. LAWYER 257, 260, 261 (I957); Marias, supra note 7.

For collateral problems, see Surrey, Current Issues in Taxation of Corporate Foreign Investment, 56 Colum. L. Rev. 815, 827 (1956); Baker and Meek, Tax Problems of Doing Business Abroad: Some Practical Considerations, 1957 Wis. L. Rev. 75 passim; Kronstein, The Nationality of International Enterprises, 52 Colum. L. Rev. 983, 986 (1952); Domke, "Piercing the Corporate Veil" in the Law of Economic Warfare, 1955 Wis. L. REv. 77.

${ }^{11}$ Louis K. Liggett Co. v. Lee, 288 U.S. 517, 557 (1933). 
of gross assets. ${ }^{12}$ Not only would this solution continue our present dual system of regulation, but, unless a federal incorporation statute were made compulsory, the net effect might simply be to add Washington, D. C., as one more place of incorporation. ${ }^{13}$ Furthermore, except in a time of business crisis, when the currents of reform are running strong, the probabilities are that a federal incorporation statute might actually be more lax than that of some of the states more committed to regulation. In any event, the drive for federal incorporation, which has evoked interest from time to time, appears to have been blunted by the enactment of the federal securities legislation administered by the Securities and Exchange Commission. ${ }^{14}$

Quite apart from historical factors, the philosophical justification for the laissez faire approach of state corporation statutes may be thought to rest in an abiding faith "in the right of men to choose their own associates, make their own arrangements, govern themselves and thus grow in responsibility without much in the way of either hindrance or help from the state." ${ }^{15}$ Although this theory has a certain tantalizing attraction, it overlooks the increasingly impersonal nature of the relationship between corporate management and the shareholders which results from the wide diffusion of shares. ${ }^{16}$ It mistakenly assumes that lax state statutes supplemented by common law provide adequate investor protection. Furthermore, it cannot be regarded as the uniform or even the prevailing view in every state of the United States.

\section{B. Attempts at Improvement of State Corporation Statutes}

\section{The period from 1928-40}

A shift in philosophy began to be discernible in the movement to overhaul and modernize corporation statutes which began in the late 1920's. The Commissioners on Uniform State Laws, after many years of study, recommended the Uniform Business Corporation Act in I928.17 In many ways, the timing was unfortunate, as the weaknesses underlying the then existing system of corporate regulation were not fully perceived. For these and other reasons, this search for uniformity ended in failure. Although the Uniform Act was adopted by the states of Louisiana (r928), Idaho (r929), and Washington (1933), with various modifications, it had

${ }^{12}$ See Berlack, Federal Incorporation and Securities Regulation, 49 HARv. L. REv. 396, 404 passim (1936). And see Reuschlein, Federalization-Design for Corporate Reform in a National Economy, 9i U. Pa. L. Rev. 9I (r942); Harold G. Reuschlein, The Schools of Corporate Reform (1950); E. G. Jennings, Federal Incorporation or Licensing of Interstate Corporate Business, 23 MinN. L. REv. 710 (1939). For an account of this movement, see Lours Loss, Securittes Regulation 58-62 (I95I).

${ }^{13}$ See Berlack, stipra note 12 , at 404 .

${ }^{14}$ See Louts Loss, Securities Regulation 61 (195I).

${ }^{16}$ The words are those of Judge Wyzanski expressing his view of the judicial policy of the Supreme Judicial Court of Massachusetts relating to shareholder derivative suits. Pomerantz v. Clark, 10r F. Supp. 341, 346 (D. Mass. 1951). But see Dodd, Amendment of Corporate Articles Under the Netv Ohio General Corporation Act, 4 U. CiN. L. REv. 129-32 (1930).

${ }^{16}$ See Adolph A. Berle, Jr. and Gardiner C. Means, The Modern Corporation and Private Property (1932); The Distribution of OWnership in the 200 Largest Non-Financial Corporations (TNEC Monograph No. 29, 1940).

${ }^{17} 9$ U.L.A. Ir 5 (1957). 
much less influence upon the revision of the Ohio statute (1927-29). ${ }^{18}$ Between 1928 and 1933, the following important commercial states made great progress in revising their statutes, using the Uniform Act as source material, but not as a barrier to careful study and drafting in the light of changing conditions: California (I929-33), Michigan (I93I), Illinois (I933), Minnesota (I933), and Pennsylvania (1933). ${ }^{19}$ In some cases, the revisions were prepared by committees appointed by the state legislatures or bar associations, assisted by corporation law specialists drawn from the law schools. Very useful reports were sometimes prepared explaining the sources and objectives sought to be accomplished. ${ }^{20}$ A number of valuable articles were written examining the many policy questions surrounding the drafting of a well-balanced corporation statute. ${ }^{21}$ By 1939 , the Uniform Business Corporation Act had been withdrawn as a "Uniform Act" and had been designated as a "Model Act" for the stated reason that its subject was not one "upon which uniformity between the states is necessary or desirable."22

\section{Developments since World War II}

a. The $A B A$ Model Act. This movement for modernization and improvement of the corporation statutes, interrupted during the war years, has been revived with some curious results. In about I940, the Committee on Business Corporations of the Section of Corporation, Banking, and Mercantile Law of the American Bar Association "was requested to prepare an appropriate form of Federal Corporation Act for use in case there should ever be a serious demand for such a statute."23 When this project was completed, the Committee was requested to prepare a model act for state use.

The initial draft of the American Bar Association's Model Business Corporation Act was published in $1946 .^{24}$ The actual drafting was done by two or three members of the Committee who were active in corporate practice in Chicago. ${ }^{25}$ This draft was largely based upon the Illinois Business Corporation Act, although the Commit-

${ }^{18}$ Ibid. See generally, E. Merrick Dodd and RaIph J. Baker, Cases and Materials on Corporations 20 (2d ed. 195I); Henry W. Ballantine, Corporattons $\$$ i I (rev. ed. 1946); Davies, Reflections of the Amateur Draftsman of the Ohio General Corporation Act, 12 Wis. L. REv. 487, 488-90 (1937).

${ }^{10}$ See E. Merrick Dodd and Ralph J. Baker, Cases and Materials on Corporations 20 (2d ed. 195I); Ballantine, op. cit. supra note i8, at 45.

${ }^{20}$ See, e.g., The Illinois Business Corporation Act Annotated With Forms (2d ed. 1947), prepared and published by the Corporation Law Committee of the Chicago Bar Association. See also E. Mierrick Dodd and Ralph J. Baker, Cases and Materials on Corporattons 20 (2d ed. i95I).

${ }^{21}$ E.g., California: Ballantine, Plans for a Modernized Incorporation Law, I6 CaLIF. L. REV. 425 (1928); Ballantine, Changes in the California Corporation Laws, 17 id. at 529 (1929); Ballantine, Questions of Policy in Drafting a Modern Corporation Law, x9 id. at 465 (1931). Ohio: Davies, supra note 18; Davies, Shares Under the Ohio General Corporation Act, 4 U. CIN. L. REv. I (I930); Dodd, Amendment of Corporate Articles Under the New Ohio General Corporation Act, 4 U. CIN. L. REv. 129 (1930). Minnesota: Hoshour, The Minnesota Business Corporation Act, I7 MrNN. L. Rev. 68g (1933), I 8 id. at I (1933); Solether and Jennings, The Minnesota Business Corporation Act, 12 Wis. L. REV. 419 (1937).

299 U.L.A. II5 (1957).

${ }^{23}$ Garrett, History, Purpose and Summary of the Model Business Corporation Act, Business Lawyer, Nov. I950, p. I.

"I Ibid.

${ }^{25}$ Ibid. 
tee did not immediately reveal the parentage. ${ }^{26}$ Revisions of the 1946 draft were made in 1950 , 1953 , 1955 , and $1957^{27}$

In an article criticizing the Model Act (as of 1953) as "an invitation to irresponsibility," a member of the Chicago bar has traced its evolution from revision to revision and has pointed out "the trend of the successive drafts toward liberality and protection of management and toward relaxation of safeguards to stockholders, creditors and the public."28 Other writers have seriously questioned the basic philosophy of the Model Act. ${ }^{29}$ The meager reports and explanations of the Committee fail to disclose this process of erosion or to indicate why it was thought necessary or desirable. ${ }^{30}$ More recently, a member of the Committee stated his belief as to the objectives sought to be attained in the Model Act: ${ }^{31}$

(a) a modern act; (b) a complete act; (c) a flexible act; and (d) a relatively simple act. If the model act does not meet these characteristics it does not accomplish its purpose of serving as a base for the revision of corporation statutes. It has been described as an enabling act, and it is primarily that. It does not purport to be a policing act. The policing must be left to blue-sky statutes and other statutes of that character, and to case law defining fraud and delineating the obligations of majorities to minorities.

One would have supposed, on the contrary, that the purpose of promulgating a model corporation act should be to propose changes which would correct existing defects and abuses in our corporation statutes and in the practices of corporation finance.

b. Loopholes and deficiencies in the ABA Model Act. The extent to which the Model Act fails to close loopholes which permit management abuse and to enact provisions for the protection of shareholders and investors may be noted by comparing some of its features with those of the California Corporations Code, one of the most advanced of the state statutes. ${ }^{32}$ Although the two statutes are similar in

${ }^{28}$ The first such disclosure $I$ have been able to find is by Garrett, Modcl Business Corporation Act, 4 Baylor L. Rev. 4I2, 424 (1952). And see Campbell, supra note 2, at 100, The Illinois statute had been rather thoroughly dissected at the time of its promulgation. See Ballantine, A Critical Survey of the Illinois Business Corporation Act, I U. CH. L. REv. 357 (1934).

${ }^{27}$ See note I supra. The 1950 draft was published in Garrett, History, Purpose and Summary of the Model Business Corporation Act, Business Lawyer, Nov. I950, p. I.

${ }^{28}$ Harris, The Model Business Corporation Act-Invitation to Irresponsibility?, 50 Nw. U. L. REv. $\dot{\mathbf{1}, 2}$ (1955).

${ }_{20}$ Wright, Current Developments in Statutory Corporation Law, 7 MraMi L.Q. 1, 6-13 (1952); Emerson, Vital Weaknesses in the Nesv Virginia Stock Corporation Law and the Model Act, 42 VA. L. Rev. 489 (1956). But see Gibson, The Virginia Corporation Law of 1956, id. at 445,449 .

${ }^{30}$ Compare the prefaces to the 1950 and 1953 revisions. Commitree on Corporate Laws, Amgri. can Bar Associatton, Modez Business Corporatton Act iv-xii (1953); Harris, supra note 28, at 3-5 passim.

s2 Campbell, supra note 2, at 99-100. (Emphasis added.)

${ }^{33}$ The California General Corporation Law of $193 \mathrm{I}$ was the product of a very energetic and public spirited state bar committee made up of practicing lawyers, assisted by Professor Henry W. Ballantine, of the University of California School of Law, Berkeley. See Ballantine, A Critical Strvey of the Illinois Business Corporation Act, I U. Chr. L. Rev. 357 (1934); Henry W. Ballantine, Corporations 45 (rei. ed. 1946). The statute was further revised in 1937. See Sterling, Amendments to California Corporation Laws, 1937: Readjusting Stock Strtctutre, 26 CalrF. L. Rev. 76 (1937). Under the supervision of the California Code Commission, in 1947, the legislation was recast in form, without a change in substance, and codified. See Buhler, 1947 California Corporations Code and Other Corporations Legislation, 35 id. at 423 (1947). 
many respects, they rest upon essentially different outlooks. The California draftsmen apparently aimed at making their statute ${ }^{33}$

... liberal enough to facilitate business transactions without undue formalities of checks and balances, of votes and consents of shareholders, and applications to courts, and at the same time not so lax that the management or the majority may manipulate the machinery to the prejudice of creditors or investors or the oppression of minority shareholders.

In. a nutshell, what the Model Act lacks and the California Corporations Code seeks to embody is an appreciation of the important role of shareholders and creditors in any prosperous business community. Although a legislature should not attempt to forge a conduit within which business transactions must be channeled, "freedom of contract" should yield to the extent necessary for statutory protection of the legitimate interests of the suppliers of corporate capital. A catalogue of some of the provisions of the Model Act and the California Corporations Code will serve to point up this difference in approach.

(x) Loans to directors. The Model Act prohibits any loans by the "corporation" to its officers or directors, but it may "otherwise assist its employees, officers and directors." ${ }^{\text {"34 }}$ Not only does the statute fail to preclude loans to such persons by subsidiary or holding companies (a possible source of evasion), but it leaves open the possible contention that "otherwise assist" would permit the corporation to guarantee obligations, although direct loans were prohibited. In contrast, the California statute forbids loans of money or property by a corporation to a director or officer of the corporation or to the directors or officers of any of its subsidiary or holding corporations, or any guarantee of his obligations by such corporations, directly or indirectly. ${ }^{35}$ The California statute is a much more tightlydrafted provision, which leaves no doubt that the intention of the framers is to preclude use of the corporate mechanism by the officer or director as a tool for his own financial manipulations.

The Model Act forbids a corporation to make loans secured by its shares, but, again, leaves open a loophole for possible evasion by the use of subsidiaries or holding corporations. In contrast, the California statute prohibits a corporation from making loans on the security of its shares or the shares of any holding corporation or subsidiary, unless the holders of two-thirds of all classes of shares, excluding the shares held by any benefited director, officer, or shareholder, consent, regardless of limitations on voting rights. ${ }^{36}$ It is to be noted that the California statute allows some flexibility by permitting such loans where an independent two-thirds majority of all shares consent to the transaction. This provision may be particularly useful in the case of a closely-held corporation.

Finally, the contrast between the two statutes appears from the facts of an actual

${ }^{33}$ Ballantine, Questions of Policy in Drafting a Modern Corporation Law, 19 id. at 465 (1931).

${ }^{86}$ Model Business Corporstion Act $\$ \$ 42,4(f), 43(\mathrm{~d})$.

${ }^{35}$ Cal. Corp. Code $\$ 823$. See the 1957 amendment, Cal. Stat. 1957, c. 278 . For the definitions of "holding corporation" and "subsidiary corporation," see CAL. CORp. Code $\$$ ir 8 .

${ }^{36}$ Id. \$ 823. Cf. N.C. Gen. STAT. \$55-22 (Supp. I955). 
transaction. A corporation wishes to finance the purchase of its shares by an officerdirector. The corporation, instead of making a direct loan, agrees to deposit funds with a bank, in escrow, with instructions to purchase the shares in the officer's name on the open market, the certificate of stock being held in escrow, pending payment of the purchase price in installments, with interest. It seems clear that this transaction would violate the California statute, although under the Model Act, the corporation might be merely "assisting" its officer-director. ${ }^{37}$

(2) Indemnification of directors. The Model Act permits the corporation to indemnify any director or officer for expenses actually and necessarily incurred by him in connection with the defense of any action except where he is adjudged liable for negligence or misconduct in the performance of duty. This provision is lifted from section 122(I0) of the Delaware Corporation Law, although that type of statutory solution had previously been subjected to very severe and justifiable criticism. ${ }^{38}$ Under this language, the director or officer would always be entitled to reimbursement for amounts paid to compromise or settle the controversy and for litigation expenses (including attorneys' fees), even though the settlement was effected without an adjudication of the issue of negligence or misconduct, without court approval of the settlement after notice to shareholders, and without a judicial determination that the defendant's conduct equitably merited reimbursement and that the amounts paid were reasonable. ${ }^{39}$ Moreover, the section is not exclusive, so that the avenue is left open for a bylaw allowing indemnity, even though the director or officer is adjudged to be liable for negligence or misconduct. In California, on the contrary, instead of encouraging or permitting undue "freedom of contract" to vary the legislative rule, the statute is made the exclusive source of the right to indemnification. In order to be entitled to reimbursement for litigation expenses, a director or officer must be "successful" in whole or in part, or the proceeding must have been settled with approval of the court. In addition, the court must find that his conduct "fairly and equitably merits such indemnity."40

By a 1957 amendment to the California Corporations Code, the corporation may also reimburse a director, officer, or employee for expenses or for any judgment or fine rendered against him in any action brought by a third person, if the board of

${ }^{37}$ Cf. Billings v. Trask, 30 Hun $3{ }_{4}$ (N.Y. Sup. Ct., Gen. T. I883); Rubenstein v. Kasprzak, 96 N.J. Eg. 406, 124 Atl. 362 (1924).

${ }^{38}$ Ballantine, California's 1943 Statute as to Directors' Litigation Expenses: An Exclusive Remedy for Indemnification of Directors, Officers and Employees, 31 Calif. L. Rev. 515, 516 passim (1943). Cf. Model Business Corporation ACr $\S 4(0)$.

Mr. Charles W. Steadman, a member of the ABA drafting committee, has explained the choice of the Delaware prototype: "It was our feeling that its simplicity was to its advantage. It is an uncomplicated statute. It has further the advantage of flexibility of leaving to each corporation and to the shareholders of the corporation the decision as to whether or not there should be indemnification." What's New in Corporation Laws-Indemnification of Directors, Business Lawyer, Jan. 1953, pp. I, 9. Cf. Del. Code ANN. tit. 8, § I22(I0) (1953).

${ }^{39}$ See Neuberger v. Barrett, I80 Misc. 222, 39 N.Y.S2d 575 (Sup. Ct. 1942); Tichner v. Andrcws, 193 Misc. 1050, 85 N.Y.S.2d 760 (Sup. Ct. 1949); Dornan v. Humphrey, 278 App. Div. 1010, 106 N.Y.S.2d 142 (4th Dep't I951); Diamond v. Diamond, 307 N.Y. 263, x20 N.E.2d 819 (1954).

${ }^{10} \mathrm{CAl}$. Corp. COde $\$ 830$. 
directors determines that he was acting in good faith within what he reasonably believed to be the scope of his employment or authority and for a purpose which he reasonably believed to be in the best interests of the corporation or its shareholders. This proviso, however, does not apply to derivative suits. ${ }^{41}$

The California statute, thus, proceeds upon the theory that the right of indemnification should be subject to rather strict statutory regulation to prevent abuse and that directors and officers should not be permitted to thwart that policy by resort to management-sponsored article or bylaw provisions.

(3) Interested directors' contracts. According to the Model Act, executive compensation may be fixed by the board of directors, unless otherwise provided in the articles of incorporation. Section $4(p)$ authorizes the corporation to establish stock option plans and stock bonus plans for directors, officers, and employees. The I955 revision contains an optional section with respect to stock options and rights; if such rights or options are to be issued to the directors, officers, or employees of the corporation or of any subsidiary, the terms of the transaction must be approved by shareholders representing a majority of the voting power. ${ }^{42}$ But apparently this requirement may be dispensed with and is subject to inconsistent provisions in the articles.

The Model Act attempts no statutory solution of the broad problem of interested directors' contracts. It is customary in the United States to insert in the articles of incorporation or the bylaws clauses permitting interested directors to contract with the corporation and allowing contracts between corporations with common directors. Many of these directors' exculpatory clauses purport to give an unrestrained authorization for contracts with directors or corporations with common directors, despite fraud or unfairness or the lack of an independent quorum or vote. ${ }^{43}$

On the other hand, the California statute seeks to displace the confusing and sometimes contradictory common-law rules, as well as all immunizing and exculpatory clauses, with specific statutory regulation. ${ }^{44}$ If a director or officer is financially interested in any corporate transactions, his presence at the meeting of the board of directors approving the transaction will not invalidate the transaction, provided his interest is known or disclosed and the transaction is approved in good faith either by a disinterested majority of the directors or by a majority of the shareholders entitled to vote, or provided the transaction is just and reasonable as to the corporation at the time it is so authorized, even though his vote was necessary for director approval. ${ }^{45}$ Whether or not one agrees with the particular solution sug-

¿1 Cal. Stat. 1957, c. 226I, \$ 3. Cf. Schwarz v. General Aniline \& Film Corp., 305 N.Y. 395, Ir3 N.E.2d 533 ( $\times 953$ ).

${ }^{12}$ Model Business Corporation Act $\$$ i8A.

${ }^{43}$ Sec Henry W. Bailanttne, Norman D. Lattin, and Richard W. Jennings, Cases and Materials on Corporations 300 (2d ed. 1953); Sterling v. Mayflower Hotel Corp., 33 Del. Ch. 293, 93 A.2d I07 (Sup. Ct. 1952).

"Cal. Corp. CODE $\$ 820$.

"Remillard Brick Co. v. Remillard-Dandini Co., rog Cal. App. 2d 405, 24x P.2d 66 (r952); Comment, Effect of Statutes on Contracts Between Corporations With Common Directors, 51 Mich. L. Rev. 705 (1953). Cf. N.C. Gen. Stat. $\$ 55-30$ (Supp. I955), which follows the California pattern, 
gested by the California statute, it seems advisable to reduce the problem to statutory regulation, thereby foreclosing immunizing or exculpatory clauses, which are usually prepared by or for management.

(4) Shareholder control of bylaw amendments. The Model Act places the power to adopt the original bylaws in the board of directors and also the power to amend or repeal them, unless the articles reserve such power to the shareholders. ${ }^{40}$ In California, the shareholders may adopt, amend, or repeal the bylaws, with the board of directors also having such power, subject to being overridden by shareholders possessing a majority of the voting power. ${ }^{47}$ Moreover, articles or a bylaw adopted by the shareholders may limit or deprive the directors of the authority to make or repeal bylaws. Although the articles or bylaws may provide for a supermajority vote of shares to alter the bylaws, the shareholders cannot be completely deprived of their amendatory power.

California does not make the power of shareholders to change bylaws dependent upon the terms of the original articles. The Model Act allows an undue "freedom of contract," for it is common knowledge that the articles are generally prepared by the promoters' or managers' attorneys with a view to giving them as free a rein as possible. To the extent that the Model Act makes it more difficult for shareholders to make changes in the bylaws, it encourages a dictatorship of directors between annual elections.

(5) Shareholder representation and voting rights. The Model Act, like the California statute, contains a mandatory provision for cumulative voting for directors. ${ }^{18}$ At the same time, however, that Act allows this policy to be frustrated by permitting the classification of directors and the staggering of their terms of office over as much as a three-year period, ${ }^{49}$ a practice expressly prohibited in California. ${ }^{50}$ Furthermore, in California, except where the articles provide for a maximum and minimum number of directors (which cannot be less than five), only the shareholders can amend the bylaws or articles to change the authorized number of directors. ${ }^{51}$ But even where the directors are authorized to adopt a bylaw fixing the exact number of directors, this may be superseded by shareholder action. If the bylaws are amended to reduce the authorized number of directors below five, the votes of shareholders holding more than eighty per cent of the voting power are necessary. ${ }^{62}$ This provision forestalls any scheme to minimize the effectiveness of cumulative voting by reducing the number of directors below five and, thus, guarantees representation on the board of directors to any shareholder or group having at least twenty per cent of the voting power. In contrast, under the Model Act, the authorized number of

except that shareholder approval must be given by a majority of the voting power, other than the shares owned or controlled by the adversely-interested directors.

${ }^{40}$ Model Business Corporation Act $\$ 25$.

${ }^{47}$ Cal. Corp. Code $\$ 500$.

${ }^{43}$ Model Business Corporation Act $\S 3 \mathrm{x}$.

${ }^{40} I d$. $\$ 35$. The board must consist of nine or more members for this section to become applicable.

${ }^{50}$ Cal. Corp. Code $\$ 805$.

${ }^{62}$ Id. \$ 50x(d). 
directors may be changed by amendment of the bylaws, and, as we have seen, the articles may vest the power to amend in the board of directors exclusively. ${ }^{53}$ Thus, another device for crippling cumulative voting is countenanced by the Model Act.

(6) Removal of directors. It has been generally held, in the absence of statute or a provision in the articles or bylaws, that shareholders may not remove a director from office before the expiration of his term, except for cause. ${ }^{54}$ The articles of incorporation or bylaws sometimes provide that a majority of the shareholders may remove a director, with or without cause, before the expiration of his term of office. ${ }^{55}$ In the absence of such a provision or statutory authority, even an overwhelming majority of the shareholders may find it difficult or impossible to remove an intrenched board of directors between annual elections. ${ }^{56}$

The authority of shareholders to remove directors at will is obviously an important safeguard and means of maintaining shareholder control over the board of directors. Accordingly, an increasing number of states (including California) have enacted statutes which authorize some specified majority of the shareholders to remove the directors at any time. ${ }^{57}$ The California statute contains an important further safeguard designed to protect the cumulative voting rights of minority shareholders where less than the entire board of directors is removed. ${ }^{58}$ On the other hand, it is surprising to find that the Model Act fails to confer a statutory power of removal upon the shareholders, although it seems to be contemplated that such a power might be conferred by the articles or bylaws. ${ }^{59}$ It should be noted, however, that the 1955 revision of the Model Act does contain an "optional section" granting a statutory right of removal, which also preserves the rights of shareholders under voting systems calling for cumulative voting and the classification of boards of directors and the staggering of their terms of office. ${ }^{60}$ Unless this optional section is enacted, however, the Model Act, as such, confers upon the shareholders no statutory right to remove the directors.

\footnotetext{
${ }^{53}$ Model Business Corporation Act $\S 25$.
}

טc Campbell v. Loew's Inc., I34 A.2d 852 (Del. Ch. I957); People ex rel. Manice v. Powell, 201 N.Y. 194, 94 N.E. 634 (IgII); Ballantine, op. cit. supra note I8, at 434; 2 William M. Fletcher, Private Corporations \$ 352 (Perm. ed. rev. repl. r954).

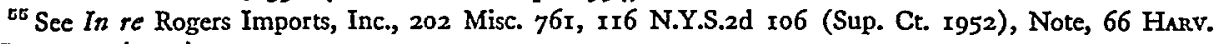
L. REv. 531 (1953).

oo See Henry W. Ballantine, Norman D. Lattin, and Richard W. Jennings, Cases and Materuais on Corporations 280 (2d ed. I953).

${ }^{67}$ Cal. Corp. Code $\$ 8$ ro; MD. Ann. Code art. 23, \$ 48 (I951); Minn. Stat. \$ 301.29 (I953); Mont. Rev. Codes ANn. $\$ 15-408$ (1955); PA. STAT. tit. 15, $\$ 2852-405$ (1936); VA. Code ANn. $\$$ I3-200 (Supp. 1956); WASH. REv. CODE $\$ 23.36 .040$ (r95I). In all, twelve states have enacted provisions for shareholder removal of directors, with or without cause. In addition, four others provide for such power, unless the charter or bylaws restrict or nullify it.

${ }^{8 B}$ CAL. CoRp. CodE $\$ 2235$. Minnesota, Ohio, Pennsylvania, and Washington also have somewhat similar legislation. Cf. In re Rogers Imports, Inc., 202 Misc. 76x, I16 N.X.S.2d ro6 (Sup. Ct. 1952); Campbell v. Loew's, Inc., 134 A.2d 852, 858 (Del. Ch. r957).

${ }^{50}$ See What's New in Corporation Laws-Removal of Diretcors, Business Lawyer, Jan. 1953, pp. 27, 30 (statement by Charles W. Steadman, member of the drafting committee).

${ }^{00}$ Model Business Corporation ACT $\$ 36 \mathrm{~A}$. The 1955 revision introduces alternative and optional provisions to certain sections of the 1953 revision. Optional subjects concern matters which may be included in a state statute, but which were intentionally omitted as not "essential." 
(7) Repurchase of shares. The Model Act permits a corporation to purchase shares out of earned surplus or, if the articles permit or two-thirds of the voting power consent, out of capital surplus. ${ }^{61}$ As the promoters of the corporation normally dictate the initial charter provisions, it would be a rare case where the corporate managers in a Model Act jurisdiction would not avail themselves of this "freedom of contract." Conferring such an unrestricted power upon the corporation to deal in its own shares sanctions abuses which are prejudicial to the rights of creditors or preferred shareholders or which may favor the inside or influential shareholders at the expense of the outside shareholders. ${ }^{62}$ In contrast, the California statute allows, with some exceptions not of general application, purchase of common shares only out of earned surplus. ${ }^{63}$ In a one-class situation, surplus arising from the reduction of stated capital may be used to purchase common shares under safeguards designed to prevent discrimination in favor of insiders. ${ }^{84}$ In a two-class situation, paid-in surplus and reduction surplus are available only for the purchase or redemption of preferred shares subject to redemption, at not to exceed the redemption price. ${ }^{65}$ Preferred shares not subject to redemption may be purchased only by the use of reduction surplus, upon reasonable and nondiscriminatory terms, at not more than the lowest liquidation price for the shares. ${ }^{68}$

(8) Grant of immunity to foreign corporations. Although the Model Act is primarily an incorporation statute, under section ninety-nine, jurisdictions enacting it are asked to sign away any right to regulate the internal affairs of foreign, or even pseudo-foreign corporations. That section, in part, provides:

A foreign corporation shall not be denied a certificate of authority by reason of the fact that the laws of the state or country under which such corporation is organized governing its organization and internal affairs differ from the laws of this State, and nothing in this Act contained shall be construed to authorize this State to regulate the organization or the internal affairs of such corporation.

This escape hatch serves as an open invitation to corporate managers to incorporate away from home if they consider the Model Act to be too restrictive, as well as insures that foreign corporations, wherever organized, will be entirely free from local regulation in the crucial area of management-shareholder relationships. Because of the limitation on regulation "in this Act," however, it is believed that the adoption of section ninety-nine would not prevent the exercise of broad powers for the protection of investors under a state blue-sky law.

Not all of the provisions of the Model Act compare unfavorably with the Cali-

${ }^{\circ 1} \mathrm{Id}$. 5 .

2 See Note, Purchase by a Corporation of Its Own Preferred Shares With Dividends in Arrears, $14 \mathrm{U}$. CHr. L. REv. 66 (1946); Note, Stock Repurchase Abuses and the No Prejudice Rule, 59 YALE L.J. 1177 (1950).

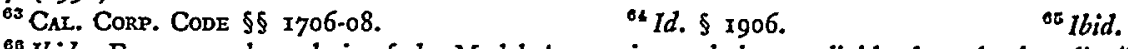

${ }^{B 8}$ Ibid. For a superb analysis of the Model Act sections relating to dividends and other distributions to shareholders, see Hackney, The Financial Provisions of the Model Business Corporation Act, 70 Hanv. L. Rev. I357 (1957). 
fornia statute; many provisions of the two acts are quite similar. For example, both provide substantial class-voting protection for preferred shareholders who may be adversely affected by charter amendments. ${ }^{67}$ Nevertheless, the foregoing comparison of the two acts on a substantial number of crucial matters, while by no means exhaustive, highlights the fact that the accent in the Model Act is upon simplicity and flexibility at the expense of fair and adequate protection of the shareholders against potential management abuse, whereas the California statute embodies many more regulatory provisions resulting in additional protection to shareholders and creditors. In short, the Model Act is misnamed. Far from being a "model," it is too simple, too flexible, and too full of loopholes and deficiencies in favor of management. It appears to be a product of either poor drafting or (what is more likely the case) too close attention to the wishes of corporate clients and too little concern for the public interest and the protection of investors. ${ }^{68}$ We have a right to expect a higher standard of performance from a quasi-public committee. It is not too much to ask that the Committee be infused with new blood and that its position on a number of vital points be re-examined.

c. The North Carolina Business Corporation Act of $1957-$ An Experiment in Corporate Regulation. The North Carolina revision program has been described elsewhere. ${ }^{69}$ This work was carried out under the supervision of the General Statutes Commission, an official state agency. The actual drafting was the work of corporation law specialists drawn from the law schools of the state. ${ }^{70}$

The draftsmen not only sought to prepare a "technically excellent enabling act," but also made a conscious effort to develop built-in safeguards for the protection of the outside shareholders. ${ }^{71}$ A number of these innovations deserve careful study. There is, for example, a mandatory dividend provision designed to prevent "squeeze plays" on minority shareholders in closely-held corporations. ${ }^{72}$ There are statutory restrictions upon the repurchase of shares, the aims of which are to prevent favoritism or discrimination among shareholders. ${ }^{73} \mathrm{~A}$ "dominant shareholder" provision re-

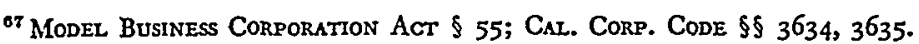

${ }^{\circ 8}$ Cf. Emerson, supra note 29, at 531-34. See Seward, The Movement for Modernization for Our State Corporation Laws, I86 Com. \& Fin. CHRon. 14, 34, 35 (1957), for a frank explanation of the motivation behind the ABA Model Business Corporation Act. Law firms and corporations "interested in corporation law" are being tapped for some $\$ x 82,000$ to finance the preparation of an annotation of the Model Business Corporation Act and the Model Non-Profit Corporation Act.

"Latty, Powers, and Breckenridge, The Proposed North Caroling Business Corporations Act, 33 N.C.L. REv. 26 (1954); Powers, Drafting a Corporation Code for North Carolina, ro ARK. L. REv. 37 (1955); Latty, Uncertainties in Permissive Sources of Dividends Under Present G.S. 55-1 I6, 34 N.C. L. Rev. 26I (1956); Latty, The Close Corporation and the New North Carolina Business Corporation Act, id. at 432 .

${ }^{70}$ Professors E. R. Latty, Duke University School of Law; I. S. Powers, Wake Forest School of Law (now at University of Florida College of Law); and M. S. Breckenridge, University of North Carolina School of Law.

${ }^{71}$ Powers, Drafting a Corporation Code for North Carolina, Io ARk. L. REv. 37, 39-4I (I955).

${ }^{70}$ N.C. Gen. STAT. $\$ 55-50$ (i) (Supp. I955); Powers, Drafting a Corporation Code for North Carolina, ro ARk. L. Rev. 37,42 (1955). Moreover, special attention is given to the problems of the closely-held corporation. See Latty, The Close Corporation, and the New North Carolina Business Corporation Act, 34 N.C. L. REv. 432 (I956).

${ }^{73}$ N.C. Gen. Stat. $\$ 55-52$ (Supp. I955). 
stricts loans to controlling shareholders as well as to officers and directors. ${ }^{74}$ Exculpatory and indemnification provisions in charters and bylaws have, in general, been banned in favor of direct statutory regulation. ${ }^{75}$ Bylaw provisions authorizing bonuses to corporate officers measured by income or volume of business have a terminal effectiveness of five years, unless renewed by a majority shareholder vote. $^{76}$

A number of provisions are specifically concerned with strengthening the position of preferred shareholders and protecting them against inequities. Conventional noncumulative preferred share contracts are prohibited; for the future, only the cumulative-if-earned variety will be allowed. ${ }^{77} \mathrm{~A}$ helping legislative hand is extended when preferred shareholders are confronted with an unfair plan of recapitalization. Class voting on charter amendments, mergers, and consolidations is mandatory, even as to preferred shares which are otherwise nonvoting. ${ }^{78}$ In the event of prejudicial changes in preferred shares, whether effected by direct charter amendment, merger, consolidation, or a "voluntary plan of recapitalization," an appraisal right is given to dissenters. ${ }^{79}$

The rights of appraisal by dissenting shareholders is enlarged in one other respect. Added to the usual provision for appraisal in mergers and consolidations is a special feature conferring an appraisal right to dissenters of the selling corporation where a business combination is effected by a sale of all assets in exchange substantially for shares of the purchasing corporation. ${ }^{80}$

Perhaps the most unique feature of the North Carolina legislation is the attempt to police a large number of potential abuses and inequities through direct legislation, rather than through the use of a strong state securities act.

One proposal, which was eliminated from the final statute, was a rather ingenious attempt to forestall circumvention of the statute by out-of-state incorporation, the "pseudo-foreign corporation" problem to which reference has previously been made. ${ }^{81}$ The draftsmen, recognizing the possibility that corporations might flee to more hospitable shores, made certain of the shareholder protective provisions applicable to "pseudo-foreign corporations." This term included ${ }^{82}$

... a foreign corporation which after the enactment of this chapter obtains for the first time a certification of authority to transact business in this State and which engages in no substantial business activity in the state or country of its incorporation, and which, by virtue of the place and character of its business and personnel, is more closely identified with the business life of this State than with any other state or country; but the term does not include a corporation formed under or by laws of the United States.

${ }^{74}$ Id. $\$$ 55-2(6), 55-22. Cf. CAL. CORP. CODE $\$ 823$, which overlooks this problem.

${ }^{75}$ N.C. GEN. STAT. $\$ 55-20,55-30$ (Supp. 1955).

${ }^{70} I d . \$ 55-16(2)(3)$.

${ }^{77}$ Id. $\$ 55-2(5), 55-40(c)$.

${ }^{78}$ Id. $\$ \$ 55-100,55-10 \mathrm{r}$.

${ }^{70} 1 d$. \$5 55-102, 55-113.

${ }^{80} \mathrm{Id}$. $\$ 55$-I13.

${ }^{81}$ Supra note 1o and text to which cited. The General Statutes Commission submitted to the 1955 North Carolina General Assembly a proposed new Business Corporations Act. S. 49 (1955).

${ }^{82}$ Id. $\$$ 55-2(II), 55-2(I2); see also id. $\$ \$ 55-19$ (c), 55-134, 55-135, 55-136. 
Space does not permit an exploration of all of the various ramifications of this statute. $^{83}$ It must be noted, however, that the jurisdictional base is that of doing business within the state and identification with the business life of the state, rather than the issue or sale of shares within the state, or even ownership of shares by residents of the state. Thus, the proposal would apparently have been applicable where a Massachusetts corporation, all of whose shareholders were and continued to be residents of Massachusetts, transferred its operations from Massachusetts to North Carolina. Under such circumstances, the policy of imposing North Carolina standards in management-shareholder relationships is questionable. Nevertheless, at least an attempt was made to solve one of the most delicate questions in the area of interstate relations: How may a state protect its general incorporation statute from subversion through foreign incorporation? It is believed that any such policing should be accomplished through administration supervision under a state securities act. The second part of this paper will be concerned with this problem.

II

\section{State Securities Acts as Instruments of Corporate Regulation}

If a state desires a general incorporation statute with more regulatory provisions to safeguard investors along the lines of the California and North Carolina statutes, some means must be found to minimize and discourage circumvention of the statutes through out-of-state incorporation. We have seen how the draftsmen of the North Carolina statute attempted to meet this problem by a limited "domestication" of quasi-foreign corporations. Another method which has not been given the recognition which it deserves is that of using the state securities acts or "blue-sky" laws as instruments of corporate regulation. The chief interest of the state in these matters is that of protecting its shareholders against unfair and inequitable share structures loaded in favor of promoters and managers. The time to check these arrangements is when the corporation proposes to issue or sell securities. Even a lax corporation statute may be strengthened by a strong "blue-sky" law, and a more regulatory corporation statute can be buttressed by a fair but effective state securities statute. In this connection, it is important to consider the various types of blue-sky laws and their strengths and deficiencies as instruments for providing a greater measure of protection for shareholders against potential management abuses.

\section{A. Types of Securities Acts}

There is no general agreement as to classification of securities acts. ${ }^{84}$ In order to highlight basic differences in approach and to point up the scope and limitations of

${ }^{83}$ The proposed statute was discussed in Latty, Pseudo-Foreign Corporations, 65 YAIE L.J. $\times 37$ (r955).

${ }^{4}$ See Dalton, The California Corporate Securities Act, I8 CaLIF. L. Rev. 115, 116-28 (x929); Smith, The Relation of Federal and State Securities Laws, 4 LAw \& Contemp. Prob. 24X (1937); Wright, Correlation of State Blue Sky Laws and the Federal Securities Acts, 26 Connell L.Q. 258 (I94I); Louis Loss, Secunities Regulation 19-44 (I95I); Lous Loss and EdWard CowetT, Blue SkX LAW I7-42, 283-84 (1958). 
the various types, my preference is for a division into four classes or combinations of classes: ( $x$ ) fraud prevention; (2) licensing of broker-dealers; (3) qualification of securities, restricted to fraud prevention by compelling "full disclosure"; and (4) qualification of securities, with the imposition of varying degrees of substantive regulation of the terms and conditions under which securities may be sold or issued.

\section{Fraud prevention}

The antifraud statutes, of which the Martin Act in New York may be regarded as the prototype, are only a step removed from the individualistic approach of the civil and criminal law. ${ }^{85}$ The attorney-general of the state is authorized to prevent "fraudulent practices" in the purchase and sale of securities by resort to the techniques of investigation, injunction, and criminal prosecution. ${ }^{88}$ Curiously enough, the Martin Act "goes no further than to say that a fraud or a violation of law which would operate as a fraud is a fraudulent practice." 87 The courts, however, have given content to the statute by reading it to embrace not only legal fraud, but also the omission or concealment of material facts which in fairness should be disclosed to the purchaser or seller of securities. ${ }^{88}$ Its purpose has been stated as being mot'only to prevent fraud, but to "defeat all unsubstantial and visionary schemes $\therefore$... whereby the public is fraudulently exploited." 80

$\therefore$ This type of statute attempts no substantive regulation and is, in fact, an ineffective fraud-prevention weapon. Securities frauds frequently are not detected until it is too late-to take preventive -measures. ${ }^{90}$ Even where discovered, a full investigation is usually necessary to determine whether there is sufficient evidence to warrant prosecution. Then, there are the inevitable delays in bringing the case to trial-with the possibility of appeal-not to mention the many legal hurdles to be surmounted in establishing all of the elements of fraud.

" On the other hand, if securities may be offered or sold only after qualification under a registration or permit system, not only is there an opportunity for administrative review prior to sale, but the enforcement problems are reduced. Failure to qualify the securities is itself a violation. After apprehension of the violator, any fraud aspects of the case may be pursued and prosecuted if the evidence is forthcoming. Prompt action may also enhance the likelihood of restitution to victims.

${ }^{85}$ N.Y. GeN. Bus. LaW $\$ 352$ et seq.

${ }^{80}$ See generally, Louis Loss, Securities Regulation 20-26 (195I).

${ }^{87}$ People v. Federated Radio Corporation, 244 N.Y. 33, 38, X54 N.E. 655, 657 (1926).

${ }^{83}$ Id. at 41,154 N.E. at 658 .

${ }^{80} 1 d$. at 38,154 N.E. at 657 .

${ }^{90}$ See, e.g., People v. Tellier, i55 N.Y.S.2d 245 (S. Ct. 1956). For the testimony of Attorney General Javits, of New York, before a House subcommittec as to the futility of coping with the uranium boom by a simple fraud statute, see Hearings before the Subcommittee on Commerce and Finance of House Committee on Interstate and Foreign Commerce on H.R. 5701, 84th Cong., 474-88 (1955-56). These hearings also contain a case history of the role played by Mr. Tellier as a banker-promoter of uranium companies. Id. at 561-95. Cf. People v. Otterman, 154 Cal. App. 2d 223, 316 P.2d 85 (1957). 


\section{Broker-dealer registration}

The second type of regulation is that of licensing the professional sellers of securities. $^{91}$ Such statutes may require the registration of brokers and dealers and their agents, ${ }^{92}$ as well as registration of the agents of original issuers of securities. Licensing of investment counsellors is a later development. Broker-dealer registration may be made an adjunct of fraud prevention-this has been done in New York. $^{93}$ It may also be used to buttress a system of securities qualification, as has been done in the federal securities legislation and under a number of state blue-sky laws. Secondary sales of securities are frequently controlled at the broker-dealer level, rather than at the stage of original issue. ${ }^{94}$ But since these statutes are aimed at dealers in securities rather than issuers, they play only a subsidiary role as instruments of corporate regulation.

\section{Securities qualification stressing disclosure}

The third type is that of requiring securities to be registered or qualified, with a view to preventing fraud by compelling full disclosure in a prospectus to be furnished to the prospective purchaser prior to sale. The Securities Act of 1933, with some exceptions, requires that new issues of securities offered by use of the mails or other channels of intertstate commerce shall be registered with the Securities and Exchange Commission, and that a prospectus (filed as a part of the registration statement) shall be furnished to the purchaser prior to the sale or, in some cases, at the time of the delivery of the security after sale. ${ }^{95}$ According to the Commission, ${ }^{96}$ its

... primary function is to require full and adequate disclosure of all material facts in connection with a putlic offering of securities so that investors may, on the basis of such disclosure, arrive at an informed judgment as to whether or not to purchase the securities offered.

Civil liabilities are imposed upon the issuer and certain other persons for misstatements or omissions contained in the registration statement and prospectus in favor of purchasers of registered securities. ${ }^{97}$

The disclosure statutes are based upon the theory that once the facts are made ac-

${ }^{22}$ See Louts Loss, Securities Regulation 26-30 (1951).

${ }^{12}$ The loopholes in the federal and New York securities statutes have created enforcement difficulties. See Hearings, supra note 90, at 477-79.

${ }^{D 3}$ N.Y. GEN. Bus. LaW $\$ 359$-e. In New Jersey, regulation is retricted to a simple antifraud statute. N.J. Rev. Stat. tit. 49 (1937).

${ }^{\circ 4}$ See e.g., Car. CoRp. CODE $\$ 25602$. See text at note 154 infra. In California, this solution has been dictated in part by the decision in People v. Pace, 73 Cal. App. 548, 238 Pac. 1089 (1925), which found supposed constitutional restrictions against requiring a broker's license for sales by a bona fide individual of personally-owned securities of which he was neither issuer nor underwriter, where the sales were for his own account and he did not engage in the business of dealing in securities. See Dahlquist, Regulation and Civil Liability under the Californa Corporate Securities Act: II, 34 CaLIF. L. REv. 344, $3^{63}$ (1946); IV, id. at 695, 719 (1946).

${ }^{00} 48$ STAT. 74 (1933), as amended, 15 U.S.C. $\$ \$ 77 a-77 a a(1952)$.

${ }^{00}$ In the Matter of Tucker Corporation, Securities Act Release No. 3236, 1947, p. I.

${ }^{07}$ Sccurities Act of $1933, \S \S \mathrm{II}, 12$, and 15,48 STAT. 82, 84, as amended, 15 U.S.C. $\$ \$ 77 \mathrm{k}, 77 \mathrm{l}$, 770 (1952); Louis Loss, Securities Regulation 982-1029 (I95I). 
cessible to a prospective investor, then if he "does not take the trouble to inform himself before risking his money, he has no one to blame but himself." 88 Despite the apparent simplicity of this approach, numerous problems arise in administration. First, under the Federal Securities Act, sales may be made in person or by telephone, without the seller being required to furnish the buyer with a prospectus in advance, as long as the prospectus accompanies or precedes any written confirmation of the sale or, in the absence of such confirmation, accompanies or precedes delivery of the security after the sale. ${ }^{99}$ Many securities are, thus, sold under circumstances where, for all practical purposes, the investor is committed before he ever sees the prospectus. Under this loophole, full disclosure is illusory, since the sale can be made by oral representations, and the prospectus serves only to inform the investor as to what he has already purchased. ${ }^{100}$ Moreover, even where the prospective purchaser does receive the prospectus, it is at least doubtful whether he will take the time and trouble to read it or whether any but the more sophisticated investors will understand this complicated document. ${ }^{101}$ Nor can it be assumed that the information will trickle down to the average investor through security analysts and financial advisers, particularly in cases of promotional or highly speculative securities. ${ }^{102}$ The most important safeguard is the very careful administrative review to which the Securities and Exchange Commission subjects registration statements and prospectuses. ${ }^{103}$

The Commission prescribes the contents of the registration statement and prospectus. In order to carry out the statutory policy, the Commission has interpreted the requirement of full disclosure in very broad terms. ${ }^{104}$ It compels compliance with

${ }^{88}$ Address by Louis Loss, Mexico Stock Exchange, June 6, x957, at 8.

${ }^{20}$ Securities Act of $1933, \$ 5,48$ STAT. 77, as amended, 15 U.S.C. $\$ 77 \mathrm{e}$ (1952).

${ }^{100}$ Byron D. Woodside, Director of the SEC Division of Corporation Finance, has said: "I think the facts of life are such that the securities . . . in promotional ventures in the uranium field and mining field generally, oil and gas and, indeed, in some of the other types of promotional issues, are sold on the basis of oral representations which convince people they are going to realize a profit if they buy, and I would guess in the vast majority of the cases, whether the issues . . were registered, or not, as a practical matter you would not be able to nail anybody under section Ir [of the Securities Act of 1933], because I do not think that is where the misrepresentation is likely to be found. It is in the conversation that occurs between the salesman and the purchaser, and the dealer and the purchaser." Hearings, supra note 90, at 81. See Louis Loss, Secunities Regulation 58-61 (Supp. 1955). The same opportunity, of course, exists for all issues.

${ }^{101}$ Cf. Cole, Morley, and Scott, Corporate Financing in Great Britain, I2 Business LAwYer 321, 370, 371 (I957); Lous Loss, Securimes Regulation 158-6r, 165-66 (1951); Douglas, protecting the Investor, 23 YALE Rev. (n.s.) 521, 523 (x934).

${ }^{102}$ Cf. Louis Loss, Securittes Regulation I66 (195I).

${ }^{103} \mathrm{Id}$. at $166-78$.

${ }^{101}$ See Charles A. Howard, I S.E.C. 6, II (1934) (a statement is false if it conveys a false impression); Commonwealth Bond Corp., I S.E.C. 13, 24 (1934) (prophecies known to be untrue when made are untrue statements of fact, since they misstate the mind of the prophet); National Educators Mutual Ass'n, Inc., I S.E.C. 208, 215 (1935) (even though all statements are literally correct, the Commission may challenge a registration statement and prospectus upon the broad basis that, taken as an entirety, the general effect is to create a false impression in the minds of prospective investors); Plymouth Consolidated Gold Mines, Ltd., I S.E.C. 139, 146 (1935) (where the effect of the share structure is to permit promoters to siphon off most of the cash contributed by investors, there must be an "adequate and succinct disclosure of the effects of these strange and curious procecdings to the investor"); Haddam Distillers Corp., I S.E.C. 37, 47 (1934) (trusteeship of other people's money demands "some warrant 
its standards by advising the registrant of shortcomings through an informal "deficiency letter" or by instituting refusal order or stop-order proceedings. ${ }^{105}$ As Professor Loss says: "While in theory the Commission's staff merely 'suggests' amendments, the practicabilities of financing do not allow any real alternative of complying." ${ }^{\text {"06 }}$

Moreover, the Commission may also be in a position to impose some substantive conditions by use of the coercive power to deny acceleration..$^{107}$ The registration statement becomes effective on the twentieth day following its filing or the filing of any amendments thereto, and the time runs from the filing of each amendment. The Commission may grant or deny acceleration "having due regard to the adequacy of the information respecting the issuer theretofore available to the public, to the facility with which the nature of the securities to be registered, their relationship tothe capital structure of the issuer and the rights of holders thereof can be understood, and to the public interest and the protection of investors." 108 Where acceleration is essential for business reasons, the language gives the Commission considerable latitude to impose some substantive regulation which goes beyond mere disclosure, as any lawyer who has been confronted with the use of this power can attest. And as Professor Davis point out, judicial review is impracticable, if not nonexistent. ${ }^{109}$

The acceleration weapon, however, is most effective when least required and is relatively impotent in cases of the greatest need. Acceleration is absolutely essential only where the securities are of sufficient soundness that a responsible underwriter is willing to give a firm commitment, if only for a limited period. The risks are too great for these underwriters to court the disasters which may ensue from failure of the Commission to grant acceleration. On the other hand, in the case of promotional or more speculative ventures, there is not the same urgency, and the registrant is in a position to wait out all efforts of the Commission to wear it down through asserting deficiencies or through stop-order proceedings. Precisely this happened in the Tucker case, where the registrant even survived a stop-order proceeding and an opinion of the Commission which was apparently for the purpose of "warning" prospective investors. ${ }^{110}$ Although the road may be long and weary and entail much

of open, fair and careful dealing"); Consolidated Mines Syndicate, 2 S.E.C. 316, 323 (I937) (a write-up of assets without any basis in sound valuation is misleading).

${ }^{10 x}$ Louts Loss, Securities Regulation 172 (I95I).

${ }^{100} \mathrm{Id}$. at 175. $107 \mathrm{See}$ id. at I75-78.

${ }^{109}$ Securities Act of I933, $\$ 8(\mathrm{a}), 48$ Stst. 79, I5 U.S.C. $\$ 77 \mathrm{~h}(\mathrm{a})$ (1952).

${ }^{100}$ Kenneth C. Davis, Administrative Law $\$ 42$ (I95I).

${ }^{210}$ Securities Act Release, supra note 96 at 3 . The public failed to understand or heed the warning. Between 1946 and 1948 , the Tucker Corporation raised some $\$ 26,000,000$ in cash through the sale of franchises, stock, and auto accessories, mostly through the sale of stock at five dollars a share. By r948, the company was bankrupt, and most of the investors' funds were lost. 'The registration statement became effective despite the "suspicions" of the SEC, which considered itself helpless to do more under a disclosure statute. See Study of the Securities and Exchange Commission, H.R. No. 2508, 82d Cong., 2d Sess. 18, 22-23, 24-29 (1952); Velie, The Fantastic Story of the Tucker Car, Collier's, June 25, 1949, p. r3. But the state blue-sky administrators were also unable to cope with this bizzarre episode. Only California barred sale of the stock as "a fraud upon the purchasers," $\$ 3,000,000$, or fifteen per cent of the issue of $\$ 20,000,000$, having been slated for sale in that state. See N.Y. Times, Aug. I, I947, p. 28, col. 3; Velie, stupra at 15,71 . 
time and expense, there is a very substantial number of issues which ultimately clear the Commission under its standard of full disclosure, but cannot meet the more exacting substantive standards imposed under the blue-sky laws of a number of states. $^{171}$

The view is widely held that the securities regulation at the federal level should be confined to the milder disclosure philosophy for a variety of reasons. Some believe that it would be unwise to give the Commission a broader power to pass upon the "fairness" of securities issues, on the ground that this would give it "life-anddeath power over virtually the entire industry of the country...."112 In view of the sharp differences in attitude vis-d-vis regulation in various sections of the country, there seems little likelihood in the near future of any expansion of the powers of the SEC in this area. Moreover, any such change would be impracticable and unwieldy without a far greater degree of administrative decentralization within the SEC than now exists, for its success would depend upon administration at the grass roots rather than from Washington.

A number of states, however, have experimented with securities statutes which do impose a considerable measure of substantive regulation upon issuers, and it is believed that these statutes hold the key to effective corporate regulation at the state level.

\section{Qualification of securities with varying degrees of substantive regulation}

This type of securities statute places less reliance upon disclosure to prospective investors and undertakes a greater degree of substantive regulation. These statutes range from the milder Uniform Sale of Securities Act, adopted by the Commissioners on Uniform Laws in $1930^{113}$ and withdrawn in $x 943{ }^{114}$ and its successor, the new Uniform Securities Act of $1956,{ }^{115}$ to more far-reaching systems of securities regulation, such as that found in the California Corporate Securities Law. ${ }^{110}$ At the risk of overgeneralization, the essential difference in the new Uniform Securities Act

111 The statistics under the Illinois Securities Law of 1933 are illustrative.

\begin{tabular}{|c|c|c|c|}
\hline & 1954 & 1955 & 1956 \\
\hline Applications filed & $\overline{155}$ & $15^{8}$ & $\overline{x 98}$ \\
\hline $\begin{array}{l}\text { Applications withdrawn for failure to qualify } \\
\text { Applications withdrawn in Illinois }\end{array}$ & I7 & 30 & 20 \\
\hline but registered with the SEC & Io & I8 & 14 \\
\hline
\end{tabular}

See Ill. Securitres Dep'T ANN. Rep. I4-15 (1954); id. at I6-18 (1955); id. at 8-10 (I956). Furthermore, it is the view of the Illinois Securities Department that these data do not tell the complete story, since many issuers who have registered their securities under the Federal Securities Act "do not cven bother to file... [under the Illinois statute] because of the additional statutory safe-guards to the public required by such Law." Id. at 15 (1954). Although the Illinois record may not be typical, since it is generally regarded as a leading state in its blue-sky administration, the conclusion seems inescapable that securities regulation in a number of states is far more effective than that of the SEC, especially with respect to promotional ventures. See Hearings, stipra note 90, at 275-90, passim.

${ }_{112}$ Address by Louis Loss, Mexico Stock Exchange, June 6, r957, at r2. Cf. Joslin, Federal Securities Regulation from the Small Investors' Perspective, 6 J. PuB. L. 219 (1957).

${ }^{113} 9$ U.L.A. 625 (1942).

${ }^{114}$ Nat'l Conference of Comm'rs on Uniform State Laws, Handoook 81 (1943).

${ }^{115}$ Louis Loss and Edward Cowetr, Blue Sky Law 245 (1958).

${ }^{11 E}$ CAL. CORP. CODE $\$ \S 25000-6104$. 
and the California statute is that the former concentrates upon fraud prevention (although it goes somewhat further in this respect than the Federal Securities Act), while the California statute may be regarded as an integral part of a broad scheme for correcting some of the inequities and defects which may otherwise arise in the practices of corporation finance. In order to compare this difference in approach, a brief description of the California system is necessary.

\section{a. The California Corporate Securities Law-a maximum regulation statute.}

(I) Theory and scope. The California statute combines broker-dealer regulalation, ${ }^{117}$ fraud prevention, ${ }^{118}$ and disclosure ${ }^{119}$ with administrative supervision over sales or issues of new securities in the state by an issuer; alteration of outstanding securities through charter amendments; ${ }^{120}$ and exchanges of securities effected through merger, consolidation, or voluntary recapitalization. ${ }^{\mathbf{1 2 1}}$

This pattern of regulation stems from a number of key provisions. With minor exceptions not of general application, no company may sell or offer for sale any security of its own issue in the state until it has applied for and secured a permit from the Corporation Commissioner authorizing the transaction. ${ }^{122}$ Every security of its own issue sold or issued by a company without such a permit is void, as are securities sold or issued in nonconformity with any provision of a permit which has been previously obtained. ${ }^{123}$

A "sale" is defined not only to include offers and dispositions of securities for value, but also exchanges of securities and "any change in the rights, preferences, privileges, or restrictions on outstanding securities," ambit all such changes effected by direct charter amendment, merger, consolidation, and voluntary recapitalizations. ${ }^{125}$ Since the statute applies to issues as well as sales,

${ }^{117}$ Id. $\$ \S 25700-13$.

${ }^{118} I d$. $\$ \$ 2550 \%, 26 \mathrm{ro4}_{(\mathrm{e})}$. There is, however, no specific section prescribing civil liability for violations of the statute. See Dahlquist, Regulation and Civil Liability Under the California Corporate Securities Act: III, 34 CaLIF. L. Rev. 543 (1946). Other articles in this series written by this leading member of the California corporate bar are found at: 33 id. at 343 (1945); 34 id. at 344 (1946); and id. at 695 .

${ }^{110}$ CaL. Corp. Code $\$ \$ 25600-04$.

${ }^{120}$ Id. $\S 25009$ (a).

${ }^{121}$ Id. $\S 255 \mathrm{ro}$. The statute establishes a Division of Corporations, the administrative head of which is the Commissioner of Corporations. According to information received from the Commissioner, the Division has approximately 140 employees, as compared with a total SEC personnel of 784 , of whom 484 are located in Washington, D.C., and only 300 in the field. See SEC ANn. REP. 197 (1957). The Division maintains offices in Los Angeles, Sacramento, and San Francisco. Over the years, fees have been adjusted with a view to meeting all costs of administering the statute, including enforcement activities. As a result of increased business activity in recent years, however, receipts from fees have exceeded the amounts appropriated for support of the agency. CALIF. STATE BUDGET, JULY I, 1958-June 30, x959, at 518. A prominent member of the California corporate bar has called it "one of the model statewide regulatory agencies." Dahlquist, Regulation and Civil Liability Under the California Corporate Securities Act, 33 Calif. L. Rev. 343 (1945). Cf. Armstrong, The Blue Sky Laws, 44 VA. L. Rev. 713, 720 (1958). ${ }^{123}$ CAL. CoRp. Code $\$ 25500$.

${ }^{123}$ Id. \$26roo. For judicial modification of the "void" rule, see Dahlquist, Regulation and Civil Liability Under the California Corporate Securities Act: III, 34 CALIF. L. REv. 543, 55x-60 (1946); Lours Loss, Securities Regulatton 962-64 (r95X).

${ }^{124}$ CAL. CORP. CODE $\$ 25009$ (a).

${ }^{125}$ See also id. $\$ 255$ ro. 
a permit is required even for the issuance of a share dividend. ${ }^{120}$ Stock splits also require a permit. ${ }^{127}$

The theory is that every issue of securities offers an opportunity to create inequities among shareholders and that any general exemption would fail to give the protection which the minority or outside shareholders need. It is possible, for example, to shift voting power between classes of shares by means of a stock split, a reverse stock split, or a share dividend. Moreover, a share dividend of preferred on common might have the effect of diluting the interest of the preferred as regards dividends, redemption, liquidation, conversion, and other rights. Shifts in priorities may also be effected through share dividends. Accordingly, rather than relying upon the class or other voting provision in the general corporation statute of the state, the Commissioner is vested with the power to review these transactions as to fairness. While, at first glance, these provisions may seem unduly to hamper legitimate business, experience has shown that enough cases arise where supervision is needed to justify the inconvenience.

The statute ${ }^{128}$ and the rules and regulations ${ }^{120}$ prescribe the contents of the application, the purpose of which (with the accompanying exhibits) is to furnish the Commission with material information necessary to appraise such matters as the nature of the business to be conducted, qualifications of the proposed management, whether the venture will be adequately capitalized, amounts of promotion securities proposed to be issued compared to funds from outside investors, proposed selling expenses, possible inequities between classes of shares, and whether the reports of engineers, appraisers, or other experts are adequate. The application is not a registration statement or a prospectus which is to be furnished to prospective purchasers as a selling document; it is prepared for the use of the Commissioner in determining whether a permit should be granted or denied. Accordingly, the document is much simpler than a registration statement or prospectus and less costly to prepare. ${ }^{130}$

The greatest departure from concepts of fraud prevention and disclosure, however, are to be found in the standards prescribed by the Commissioner for authorizing and denying permits. On original issues of securities, the Commissioner is to issue a permit only if he finds "that the proposed plan of business . .. and the proposed issuance of the securities are fair, just, and equitable, that the applicant intends to transact its business fairly and honestly," and that the securities proposed to be issued and the methods of issuing and disposing of them "are not such as, in his

\footnotetext{
${ }^{120}$ See Dahlquist, Regulation and Civil Liability Under the California Corporate Securities Act, 33 Calif. L. Rev. 343, 35I (I945).

${ }^{127}$ Ibid. For the controversy whether the "sale" of treasury shares is an "issue" of a new security, see Dahlquist, Regulation and Civil Liability Under the California Corporate Securities Act: II, 34 id. at 344, 374, 379 (1946); Ballantine, The Curious Fiction of Treasury Shares, id. at 536.

${ }_{128}$ CAL. CORP. CODE $\$ \$ 25502-05$.

$129 \mathrm{CAL}$. ADM. CODE tit. IO, c. 3 , subc. $2, \S \S 3$ r8-32. These rules and regulations are reprinted in I CCH BLUE SKY L. REP. I9 86Ir-5I (I954).

${ }^{130}$ The cost of compliance with state and federal securities regulation is especially acute for small business. See Murphy, The Big Worry of Small Business: Money, Fortune, July 1957, pp. 120, 122, 123; Louts Loss, Securittes Regulation 400-03 (I951); id. at 400-01 (Supp. 1955).
} 
opinion, will work a fraud upon the purchaser"; otherwise, he shall deny the application, refuse the permit, and notify the applicant in writing of his decision. ${ }^{131}$ In cases of issues of securities in exchange for outstanding securities, claims, and other property interests, including cash, pursuant to a merger, consolidation, or voluntary recapitalization, application for approval must be made to the Commissioner, who is authorized to approve the terms and conditions of the exchange, after a hearing on the fairness, at which all persons to whom it is proposed to issue such securities may appear. After the hearing, the Commissioner may refuse the permit "if in his opinion the plan is not fair, just, or equitable to all security holders affected. ${ }^{132}$ Thus, all issues are subjected to the litmus test of fairness to the entirety of the security holders affected. ${ }^{133}$

(2) Function and contents of the permit. Unlike the Federal Securities Act and other registration statutes, the Commissioner does not "register" the securities by making an order to that effect or by entering the securities in a register; ${ }^{134}$ he issues, instead, a written permit to the applicant authorizing the issue or sale of the securities. The permit generally contains: (I) recitals which are somewhat comparable to a summary prospectus; (2) the authority to issue or sell the securities, setting forth the price, maximum selling expense (including commissions), the methods and terms of payment, and the purpose to which the proceeds shall be applied; and (3) the conditions imposed in the permit, if necessary, to make the proposed issue of securities "fair, just, and equitable."13

The conditions are most commonly imposed in connection with promotional and highly speculative ventures. ${ }^{138}$ First, the amount of "promotional shares" which may be issued is limited and may not exceed an ultimate right to participate in dividends and assets of more than fifty per cent. ${ }^{137}$ Promotion shares include contemporaneous sales of "cheap stock" to promoters and underwriters at a price substantially below the public offering price, as well as prior sales of such stock, unless a change of conditions since the time of issuance justifies the differential between the price of the earlier sale and the current offering price to the public. ${ }^{138}$ They also

${ }^{132}$ CAL. CORP. CODE $\$ 25507$.

${ }^{183}$ Id. $\S 25510$. (Emphasis added.). For an evaluation of the California system as compared to judicial control, see Orschel, Administrative Protection for Shareholders in California Recapitalizations, 4 Stan. L. Rev. 215 (1952). And see Dahlquist, Regulation and Civil Liability Under the California Corporate Securities Act: II, 34 Calif. L. Rev. 344, 350-62 (I946).

${ }^{133}$ See, e.g., In the Matter of Richardson Corporation, Cal. Corp. Comm'r. File No. SF 622275 , SF 31266 (1948), discussed in Orschel, supra note 132 , at 223. In determining that a statutory merger was not "fair" to all of the security holders affected, the Commissioner took cognizance of the fact that the vote of preferred shareholders included the vote of controlling persons with an adverse interest. See SEC, Report on the Study and Investigation of the Work, Activities, Personnel, and Functions of Protective and Reorganization Committees pt. 7, at 148-87 (1938); cf. Gibson, supra note 29, at 621 .

134 Cf. UNIFORM SALE OF SECURITIES ACT of x930, $\$ 8,9$ U.L.A. 625, 64I (1942); UNIFORM Securities Act $\S 304$ (c), Louis Loss and Edward Cowetr, Blue Sky Law 305 (r958).

${ }^{135}$ CAL. CORP. CODE $\$ \$ 25507-09$.

${ }^{130}$ See generally CAL. ADM. CODE tit. Io, c. 3, subc. $2, \$ 368-42$ r.

${ }^{187}$ Id. $\$ \$ 368.2,368.6$.

${ }^{188}$ Id. $\$ 368$. 
embrace shares issued for past services or for intangible assets of unproven value because of the absence of an established earnings record. ${ }^{130}$ Second, promotion shares are ordinarily limited to common shares, as to which a number of conditions are imposed in the permit. If the promotion shares may, as a class, elect a majority of the board of directors, a condition is imposed that the voting right as a class terminates if the company fails to pay an annual dividend of at least five per cent on its outstanding shares (exclusive of promotion shares) for two years, whether or not consecutive. ${ }^{140}$ They must carry a waiver of dividend rights (currently five per cent) until the shareholders who have paid cash or its equivalent receive such a dividend, which is cumulative, after which the promotion shares receive a similar dividend; thereafter, all shares participate ratably. ${ }^{141}$ The right to participate in assets upon liquidation is also waived until the shareholders who have paid cash or its equivalent receive back their investment. ${ }^{142}$ Third, a new company financing by a public offering of securities may be compelled to impound a minimum amount of proceeds deemed necessary to launch the enterprise until the specified amount is raised. ${ }^{143}$ Finally, to prevent the promoters from "bailing out" by selling their stock and walking off from the enterprise while it is still in the promotional stage, promotion shares must be placed in escrow with an escrow holder approved by the Commissioner, and transfers are allowed only with his permission..$^{144}$

Other conditions may be imposed where vitally necessary to make the securities "fair, just, and equitable." For example, selling expenses are limited to twenty per cent of the selling price. They include indirect forms of compensation to promoters and underwriters, such as stock options, warrants, and other forms of "banditry" which would permit the siphoning off of an excessive amount of profits if the venture should prove successful. ${ }^{145}$ The price to the public may itself be limited where the ratio of the proposed offering price to past earnings is unreasonably excessive. ${ }^{146}$

(3) Scope of exemptions. The California statute follows the usual pattern of exempting certain securities and certain transactions, irrespective of the type of security, but the nature and scope of these exemptions are more limited than is customary in two important respects. First, there is no exemption of new issues of securities simply because they have been previously listed upon a national securities exchange. The theory is that merely listing a security for trading confers no badge

139 Ibid.

${ }^{140}$ Id. $\S 368.5,373$. The regulations are silent as to whether any right of rcinstatement cxists.

141 Id. $\$ 372$.

${ }^{142}$ Ibid.

${ }^{143} I d . \$ \$ 393-402$.

144 Id. $\$ \$ 370-7 x$.

${ }^{146}$ Id. $\$ \S 349-56$.

${ }^{146}$ Id. $\$ \$ 337-45$. The Commissioner will grant exceptions to his rules on application for a closed permit, where the prospective purchasers are informed investors, if all shares are escrowed so that subsequent sales need his consent. See Henry W. Ballantine and Graham L. Sterling, Jr., Caltiornia Corporation Laws $\$ 461$ (1949). 
entitling it to immunity from regulation. The Great Sweet Grass swindle, ${ }^{147}$ involving a security listed on the American Stock Exchange, is a recent classic example which proves the point. We live in an age of mergers, where shifts of control may take place quickly through such devices as a negotiated purchase, a sale of assets, a merger, or a stock acquisition. ${ }^{48}$ Moreover, any such exemption would cut down the Commissioner's power to review voluntary recapitalizations, mergers, and consolidations for "fairness."

Second, the California statute rejects the idea of a small issues exemption of corporate securities, based upon private offers, amount of securities, or the number of offers or sales, the theory being that such exemptions are neither necessary nor advisable. ${ }^{149}$ A "private-offering" exemption when applied to corporate securities has proved to be much too vague and susceptible of evasion. ${ }^{150}$ Accordingly, in California, such offerings are screened by the Commissioner. In the case of a proposed private offering, an application may be made for a closed permit authorizing the sale of securities to a selected group of persons. ${ }^{151}$ If the Commissioner is satisfied that the members of the group are reasonably informed investors, a closed permit is issued, authorizing the sale of a maximum amount of securities to any or all such persons. If a public offering is involved, the proper procedure is to request an open permit to make offers to the public indiscriminately.

The Commissioner's files reveal many reasons why an exemption based upon the number of offerees or volume of sales is rejected. For example, in one case, a California school teacher was induced to invest her life savings of $\$ 80,000$ in a Texas insurance annuity promotion..$^{152}$ To exempt any such offer or sale would simply open up another avenue of escape from effective regulation and thus encourage fraud. Furthermore, a real danger exists that additional corporations might

${ }^{117}$ In the Matter of Great Sweet Grass Oils, Ltd. and Kroy Oils Ltd., Securities Exchange Act Release No. 5483, CCH Fed. SEc. L. REP. I76,516 (r957); Klaw, The Great Sweet Grass Swindle, Fortune, Aug. 1957, p. I34.

${ }_{168}$ The mechanics of the Great Sweet Grass swindle revolved around an acquisition of control of a Canadian corporation by a Canadian promoter for an expenditure of \$150,000. 'The corporation's shares were listed on the American Stock Exchange. The corporation, through a series of "mergers," subsequently issued, in Canada, some 2,800,000 shares, which were resold in the United States without SEC registration under a claim of exemption by virtue of SEC Rule 133, I7 C.F.R. $\$ 230.133$ (Supp. 1957). The returns to the promoters were approximately as follows: gross returns, $\$ 13,000,000$; cost of shares to promoters, $\$ 3,500,000$; commissions to boiler-room operators, $\$ 2,000,000$; net profit to promoters, $\$ 7,500,000$. See Klaw, supra note 147 , at 178 .

${ }_{140}$ Domestic \& Foreign Pet. Co. v. Long, 4 Cal. 2d 547, 5I P.2d 73 (x935); Cecil B. DeMille Productions v. Woolery, 6I F.2d 45 (9th Cir. I932).

${ }^{100}$ See In re The Crowell-Collier Publishing Co., Securities Act Release No. 3825, CCH FED. SEC. L. Rep. I76,539 (x957); SEC v. Ralston Purina Co., 346 U.S. Ix9 (1953). On the difficulties in the SEC enforcement program, see 23 SEC ANN. REP. I-9 (1957).

${ }^{151}$ See Domestic \& Foreign Pet. Co. v. Long, 4 Cal.2d 547, 5x P.2d 45 (9th Cir. 1932); Dahlquist, Regulation and Civil Liability 'Under the California Corporate Securities Act, 33 CaLIF. L. REv. 343, 359 (1945).

${ }^{15}$ Cal. Corp. Comm'r File No. SF K.P. Chartier (Alpha) (1955). The offer was made in California without a permit. Full restitution was eventually obtained. Compare the enforcement difficulties engendered by the "isolated sale" and "sale to stockholder" exemptions found in the Florida statute. FlA. Stat. ANN. \$ 517.06(3) and (4) (Supp. 1957), discussed in Robinton and Sowards, The Florida Securities Act: A Re-Examination, 12 Misar L. Q. I, 4-5 (1957). 
be proliferated merely to take advantage of any such exemption. In view of these possibilities, it seems unrealistic to rest an exemption either upon the number of offerees or upon the volume of sales. The legislative policy appears to be based upon the theory that the closed permit procedure provides a safety valve for small issues, without unduly hampering legitimate business or releasing most of the steam from the Commissioner's enforcement machinery in this area.

(4) The problem of the foreign issuer. A necessary step in preparing a nationwide distribution of securities is that of coordinating the SEC registration with the blue-skying at the state level. Under the California statute, a permit to issue or sell securities must be obtained if the issuer is a California corporation, regardless of where the sale or issue takes place. ${ }^{153}$ Suppose, however, $X$, a Delaware corporation, with its principal place of business in New York and with numerous shareholders residing throughout the United States, including California, proposes to market an issue of securities on a national basis. The securities will be underwritten under a firm commitment, and the underwriters will resell the securities either directly or through selected dealers. The shares will be registered with the Securities and Exchange Commission. The closing will take place in New York, and the shares will be resold in California by licensed California brokers and dealers.

Since a secondary rather than a primary sale in California is entailed, no application for a permit for the corporation to issue or sell the securities is necessary; the only general requirement under the statute is that advertising literature to be used in California by brokers or dealers be filed with the Commission at least one day prior to use. ${ }^{154}$ The usual practice is for one of the principal underwriters who is a registered California dealer to file the prospectus and other advertising and selling material with the Commissioner shortly after filing the registration statement with the SEC. If the securities and the terms of sale meet the Commissioner's standards, the underwriters are advised that the material may be used upon supplying any missing data, such as the price. Frequently, the dealer furnishes this information by telegram. On the other hand, if the Commissioner, after a review of the prospectus, finds that the sale of the security would be "unfair, unjust, and inequitable," he may notify brokers and dealers to that effect in writing, and sales in California are thereafter forbidden until the Commissioner subsequently withdraws his objection. ${ }^{155}$

The practical result is that most national issues of foreign issuers registered with

${ }^{153}$ See Dahlquist, Regulation and Civil Liability Under the California Corporate Securities Act: II, 34 Calif. L. Rev. 344, 384 (1946). When the articles of incorporation of a California corporation are filed with the Secretary of State, he gives notice of this requirement. And see CAL. Conp. Cope $\$ 4 I 13$ as to filing of a "certificate of clearance" from the Corporation Commissioner in case of merger or consolidation.

${ }^{154}$ CaI. Corp. Code $\$ 25602$; Cax. Adm. Code tit. xo, c. 3, subc. 2, $\$ \S 840-842 ;$ scc Dahlquist, Regulation and Civil Liability Under the California Corporate Securities Act: II, 34 CuL1F. L. Rev. 344, $380-84$ (1946).

${ }^{105}$ CAí. CORP. CODE $\$ 25707$. It is this rather obscure section which plugs a supposed loophole which Professor Loss has noted in the California statute with respect to the secondary sale of securitics. See Lours loss and Edward Cowetr, Blue Sky Law 204 (1958). 
the SEC and sold under a firm commitment to responsible underwriters for resale in California can be processed without delay or difficulty. Problems will arise only where the issue fails to meet the Commissioner's substantive standards. If the securities are to be sold under a "best efforts" arrangement rather than a firm commitment, the Commissioner regards the underwriter as an agent of the issuer and the corporation itself must file an application for a permit. ${ }^{156}$

In case the $X$ Corporation offers securities to its California shareholders, whether pursuant to a rights offering or an exchange offer to be made in connection with a voluntary recapitalization, merger, or consolidation, a permit must be obtained from the Corporation Commissioner, since a "sale" takes place in the state. ${ }^{157}$ It has also been seen that the statute embraces "issues" as well as "sales," so that even the issuance of a stock dividend to California shareholders requires a permit. The California Attorney General has ruled, however, that a foreign corporation doing no business in California may issue a true stock dividend to California shareholders without the necessity of a permit. ${ }^{158}$ Thus, suppose that a Massachusetts corporation not doing business in California issues all of its shares to residents of Massachusetts. Later, a single shareholder moves to California. Under the Attorney General's ruling, no permit would be required to issue to him a stock dividend. Although the question is unresolved, it is believed that a contrary result would be reached if the foreign corporation were engaged in business, or maintained a commercial domicile, in California. ${ }^{152}$ Various interested groups have so far been unable to agree on a formula to take care of the problem of the foreign issuer with an insubstantial number of California shareholders. It would seem feasible, however, to give the Commissioner statutory power to issue rules and regulations exempting some of these transactions, either by general rule or by order upon simple notification, if he finds that the enforcement of the statute with respect to such transactions is not necessary in the public interest or for the protection of investors. ${ }^{\mathbf{1 6 0}}$

The broad control over foreign issuers found in the California statute has one final value. It enables the Commissioner to impose minimum standards for securities upon foreign corporations who choose to issue or sell securities in California. $\mathrm{He}$ has always used this power sparingly. For example, although mandatory cumula-

${ }^{156}$. See Dahlquist, Regulation and Civil Liability Under the California Corporate Securities Act: II, 34 CALIF. L. Rev. 344, 383 (1946).

${ }_{167}$ Professor Loss suggests that a failure to exempt an offering by a foreign issuer to existing shareholders pursuant to pre-emptive rights may be unconstitutional under the commerce clause. Lous Loss and EDWARd CowetT, Blue Sky LAW 377 (1958). As regards foreign issuers not doing business in the state, it would seem that primarily due process considerations are involved and that these are probably insubstantial. Cf. Travelers Health Association v. Virginia, 339 U.S. 643 (r949); McGee v. International Life Insurance Co., 355 U.S. 220 (1957).

${ }^{158}$ Op. Cal. Att'y Gen., Oct. 8, 1929; cf. 17 OPS. CAL. ATT'Y GeN. 217, 222, 223 (195I); Lours Loss AND Edward CowetT, BLUE-Sky LAW 204 (1958). For conflict-of-laws problems, see the excellent article of Loss, The Conflict of Laus and the Blue Sky Laws, 7 I HARv. L. REv. 209 (1957), reprinted in Loss AND COWETT, op. cit. supra c. 5.

${ }^{150}$ See Dahlquist, Regulation and Civil Liability Under the California Corporate Securities Act: II, 34 Calif. L. Rev. 344, 385 (1946).

${ }^{100} \mathrm{Cf}$. Securities Act of $1933, \S 3$ (b), 48 STAT. 75, as amended, I5 U.S.C. $\$ 77 \mathrm{C}$ (1952). 
tive voting has been a state policy for domestic corporations since $1879,{ }^{101}$ foreign or quasi-foreign corporations have not been compelled to insert a cumulative voting clause in their articles of incorporation where cumulative voting is permitted but not required by the state of incorporation. In October 1956, however, Western Airlines, Inc., a Delaware corporation, sought to amend its certificate of incorporation to eliminate cumulative voting. ${ }^{162}$ The company operates airlines in twelve western states, but none in Delaware. ${ }^{163}$ Its shares are owned by some 7,000 shareholders residing in every state in the Union and in several foreign countries, but its principal headquarters are located in California and it has many California shareholders. ${ }^{104}$ At the time of the sale and issuance of its shares to California residents pursuant to a permit from the Corporation Commissioner, the Company's certificate of incorporation allowed cumulative voting for directors. At the annual meeting of stockholders, held in April 1956, a group opposing the management elected two of the corporation's thirteen directors by the use of cumulative voting. Steps by the management to eliminate that right followed. The proposed amendment was approved at a special meeting at which approximately eighty-seven per cent of the shares voted, fifty-nine per cent voting for and twenty-eight per cent voting against the amendment. In view of this substantial opposition, ${ }^{165}$ early in 1957 , the California Corporation Commissioner twice denied the company's application for a permit to change the rights of the outstanding shares in this respect, the theory apparently being that such modification would be unfair and inequitable to those California shareholders who might, by cumulating their votes, obtain representation on the board. A petition by the company to the Los Angeles Superior Court resulted in referring the matter back to the Commissioner for another hearing, and the matter is still pending. If the Commissioner's position is sustained, it will clear up existing doubts as to the power of the Commissioner to impose reasonable conditions upon foreign corporations who choose to market their securities in California and to supervise voluntary reorganizations, recapitalizations, and mergers. It will also point the way for a state to use a securities statute as a regulatory device to prevent the circumvention of its general corporation statute by out-of-state incorporation. ${ }^{100}$

b. The Uniform Securities Act-a "mild" regulation statute. The new Uniform Securities Act is the third attempt to achieve uniformity in the area of state securities regulation. In 1930, the National Conference of Commissioners on Uniform State Laws and the American Bar Association approved a Uniform Sale of Securities

${ }^{102} \mathrm{CaL}$. Consr. art. xii, $\$ 12$ ( 1879 ), formerly made cumulative voting for directors mandatory. Wright v. Cent. Cal. C. W. Co., 67 Cal. 532, 8 Pac. 70 (1885). Although this section was repealed in 1930, the right was preserved by statute. CAL. CoRp. Code $\$ 2235$.

${ }^{162}$ See Western Airlines, Inc., Ann. Rep. 6 (1956).

${ }^{183}$ See Walker's Manual of Pacific Coast Securitres 463 (1957).

164 Id. at 464; Western Atritines, Inc., AnN. Rep. 6 (I956).

${ }^{165}$ See Western Arruines, Inc., Ann. Rep. 6 (1956); Cal. Corp. Comm'r File No. SF 4053 (1956).

${ }^{100}$ The Chairman of the ABA Committee on Corporation Laws finds this statutory solution "ridiculous" and suggests a hard "sell" by corporations to eradicate it. Seward, stpra note 68, at 34 . 
Act. ${ }^{107}$ The Act was not an outstanding success, ${ }^{168}$ and in 1943 it was dropped from the list of Uniform Acts. ${ }^{169}$

In 1947, a second effort was made by the same agencies, working through a joint committee of practicing lawyers composed of members of the Conference Section and the Committee on State Security Laws and Regulations of the American Bar Association Section on Corporation, Banking, and Mercantile Law. ${ }^{170}$ This committee prepared three tentative drafts of a Uniform Securities Act, ${ }^{171}$ but a hopeless deadlock ensued between industry representatives and some blue-sky lawyers, on the one hand, who took the view that the draftsmen were too regulation-minded, and state securities administrators, who were convinced that the movement was designed to strip the regulators of their essential powers. ${ }^{172}$ In view of this impasse, the third draft was withdrawn at the 1953 meeting of the National Conference, and it was recommended that a "thorough background study" should be made and cooperation sought from the National Association of Securities Administrators. ${ }^{173}$

${ }^{107}$ UNIform SAle of Securities ACT of I930, 9 U.L.A. (I942).

${ }^{108}$ The Act was adopted with modifications in Florida (r93I), Hawaii (I93I), South Carolina (1937), Oregon (1939), and Louisiana (1940). 9 U.L.A. 289 (Supp. I950).

100 Supra note II4.

${ }^{270} 72$ A.B.A. REP. 98 (1947). For an account of the work of this committee, see Blair-Smith, More on the Project for a Uniform Sectrities Act, Business Lawyer, July 1956, p. Ix.

${ }^{171}$ These drafts (1949, I95I, and 1953) apparently were published in mimeograph form. Only the last two drafts have been available to the writer. See Nat'L CoNFERENCE of CoMm'rs on UNIFORM State Laws, Uniform Securities Act (2d tentative draft r95I); id. (3d tentative draft 1953); BlairSmith, supra note I70, at II2.

173 Sce Blair-Smith, stipra note 170 , at 112.

${ }^{173} \mathrm{Id}$. at II3. How the deadlock was broken is somewhat obscure, but it undoubtedly hinged upon the decision to prepare a tripartite act representing the three different approaches to state securities regulation. See note 178 infra.

The source of the three-part structure is less puzzling. Mr. Murray Hanson, general counsel of the Investment Bankers Association of America, in 1947 suggested two uniform acts-one of the "fraud" type and one of the "dealer-registration" type, "so that basically there would be a model law available of whichever of the current types the people of a given state might desire." Hanson, The Need for Uniformity in Our Securities Laws, in Nat'L Ass's of Securities Adm'rs, Proceedings 55 (r947), reprinted in I66 Com. \& Fin. Chron. I420 (I947). In 1951, Professor Loss picked up the ball, but suggested the possibility of "three new acts, one for each of the three types of states," as he had then classified them. Louis Loss, Securimes Regulation 45 (195r).

Professor Loss has also shed light on the deadlock-breaking episode at the 1953 meeting of the National Conference: "The 1953 meeting of the Conference was held in Boston, and Commissioner Edward L. Schwartz of the Boston Bar, Chairman of the Conference's Subcommittee on the Uniform Securities Act, invited me to attend the meeting of the parent section of the Conference. That section disapproved the third draft-and was about to recommend to the Conference that the entire idea of a uniform or model securities statute be dropped-on the ground that the legislative philosophies of the states were too diverse. But the members reconsidered when it was suggested that a model statute might be drafted in several parts, each corresponding to one of the basic regulatory philosophies. Thus, Part I might deal with fraud, Part II with broker-dealer registration and Part III with securities registration. Then a fourth part might contain the general provisions (definitions, exemptions, rule-making powers and so on) which would be essential under any of the philosophies. Under this scheme of things a state like New Jersey which wanted to continue with a pure "fraud" philosophy might adopt only Parts I and IV; a state like Pennsylvania which wanted to combine anti-fraud provisions with a system of brokerdealer registration might adopt Parts I, II, and IV; and most of the states, which follow all three philosophies, might consider the entire statute. This basic approach-I wish I could say it were my own, but it has a rather mixed paternity-was received with some enthusiasm, and the Conference's committee was instructed to prepare a fourth draft accordingly." Nat't Ass's of Securities Adm's, Proceedings 37 (1954). 
The upshot was that in July 1954, the Harvard Law School undertook such a study under the direction of Professor Louis Loss, assisted by Mr. Edward M. Cowett. ${ }^{174}$ A proposed Uniform Securities Act with final draft and commentary was published two years later. ${ }^{175}$ The prestige of the Harvard Law School and the eminence of Professor Loss in the field of federal securities regulation give the study a special significance, and it is likely to have a wide influence upon state securities legislation in the coming years. ${ }^{176}$ It seems unnecessary to praise the many good features of the new Act, including the ingenious statutory proposal for solving the conflict-oflaws problems in the regulation of interstate sales of securities. ${ }^{177}$ The policy questions in any such proposal, however, are of such paramount importance that it seems appropriate and permissible to attempt a critical analysis of the basic provisions which have been framed to displace existing state legislation.

(I) Theory and scope. A unique feature of the new Act is that it rejects the idea of complete uniformity in favor of what is essentially a three-part structure representing the three basic approaches to regulation: ( 1 ) fraud prevention, (2) broker-dealer regulation, and (3) registration or qualification of securities where an administrator has the specific duty to examine the securities and the power to exclude securities which fail to meet the state's minimum standards. The theory is that although a state may adopt only one or a combination of these regulatory schemes, if the Act should receive widespread acceptance, there will at least be uniformity within any particular system..$^{178}$

The quest for uniformity seems to have resulted from the "needless complexities" of the state securities statutes. ${ }^{179}$ Professor Loss has said: "This welter of diverse state laws make one almost literally scream for a uniform act-especially if he happens to be preparing an issue for nationwide distribution." 180 Some law office juniors who are responsible for blue-skying a nation-wide offering and coordinating it with an SEC registration may be surprised to learn that the accomplishment of this objective "has some of the aspects of a minor miracle."181 Since the fraud-type statutes pose no problems from the standpoint of uniformity and broker-dealer regulation offers problems of only minor significance, it is apparent that efforts at cor-

${ }^{174}$ Ibid. For further background, see Loss and Cowett, An Interim Report on the Harvard Latv School Study of State Securities Regulation, Business Lawyer, Jan. 1955, p. 15, passim; Loss, Current Status of the Uniform Securities Act, 12 id. at 26 (1956).

${ }^{175}$ Louts Loss and Edward Cowett, A Proposed Uniform Securities Act-Final Draft and Commentary $(x 956)$. See note 3 , supra. The new Uniform Securities Act will hereinafter be citcd as the UNIFORM SECURITIES ACT-1956.

${ }^{170}$ The Uniform Securities Act- 9956 has been adopted with modifications in Kansas (1957) and Hawaii (1957). Virginia patterned its r956 statute upon an earlier draft. Seven other states have adopted one or more sections of the Act. See Lours Loss and EDward Cowetr, Blue Skx LAw app. Il (1958).

${ }_{177}$ Uniform Securities Act-r956, $\$ 414$. See Loss, The Confict of Laws and the Blue Sky Latus, 7r Harv. L. Rev. 209 (1957), reprinted in Louts Loss aNd Edward Cowetr, Blue SKY LAw C. 5 (1958).

${ }^{278}$ Louts Loss and Edward Cowetr, Blue Sky Law 236-38 (1958).

${ }^{270}$ Loss and Cowett, An Interim Report on the Harvard Law School Study of State Securities Regulation, Business Lawyer, Jan. 1955, p. 15.

${ }^{180}$ Louis Loss, Securities Regulation 44 (195I).

${ }^{18 x}$ Address by Louis Loss, Mexico Stock Exchange, June 6, 1957, at 7. 
rective measures through the medium of uniformity would have to center upon the provisions relating to registration of securities. ${ }^{182}$

The system for registration of securities follows the pattern established in the earlier Uniform Acts. As in the I 930 and 1953 drafts, securities may be registered by notification ${ }^{183}$ and by qualification. ${ }^{184}$ They may, however, also be registered by coordination, a new concept developed to correlate state securities registration with registration under the Federal Securities Act of $1933 .{ }^{185}$

The simple notification procedure is available to companies which have been in existence for at least five years and which for the preceding three years have not defaulted on any senior security and have had average earnings of at least five per cent on the common shares. ${ }^{186}$ This procedure may be used irrespective of any changes in management or other conditions which may make the statutory tests unreliable. Registration by notification becomes effective two full business days after the filing of a statement or an amendment, in the absence of a stop order proceeding or the order itself. ${ }^{187}$

Under the coordination method, the registration statement filed under the Federal Securities Act of 1933 may be used to effect state registration for the same offering. ${ }^{188}$ One objective of the coordination procedure is to streamline compliance with the state statute "without sacrificing the traditional regulatory philosophy of the states to the disclosure philosophy of the federal statute." 189 Another is to avoid "a mad lastminute mass of telephone calls and telegrams in order to make certain that the issue is cleared with the states by the time the registration statement becomes effective at the SEC."100 These purposes are accomplished by making the state registration statement operative at the moment the federal registration statement becomes effective, if (I) no stop order has been issued; (2) the registration statement has been on file with the state administrator for ten days; and (3) a statement of the

\footnotetext{
${ }^{182}$ See Blair-Smith, supra note I70, at 112 . James E. Dunlap, of the Los Angeles bar, has pointed out that "most of the pressure for the uniform law [Uniform Securities Act-r956] has come from the large brokerage houses and their attorneys who are well acquainted with the laws of all 48 states." Dunlap, Uniformity Achieved by Proposed Uniform Securities Act, in Los ANGeles BAR Ass'N CoMm. on Corporations app., at I (1957).

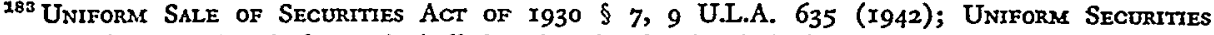
Acr $\$$ 4-I (3d tentative draft r953) (called registration by description).

186 UNIFORM S SLE OF SeCURITIES ACT OF 1930, § 8, 9 U.L.A. 643 (1942); UNIFORM SECURITIES ACT \$ 5-I (3d tentative draft $x 953$ ).

${ }^{185}$ Cf. Smith, stupra note 84 , at 252-55; Wright, supra note 84 ; Lours Loss, Securities Regulation 44-88 (195I).

${ }^{189}$ UNIFORM SECURITIES ACT-r956, 302.

${ }^{187}$ Id. $\$ 302(c)$.

${ }^{188}$ Id. $\$ 303$.

${ }^{180}$ Louis Loss and Edward Cowetr, Blue Sky Law 291 (1958). (Emphasis by authors.)

${ }^{100}$ Ibid. It is belicved that Professor Loss greatly exaggerates the mechanical problem. While time, paper work, and telephone and telegraph expenses are necessary to blue-sky a nationwide issue, when weighed against the other tasks of the lawyer in getting out the issue, they are of minor magnitude. $C f$. Dean, The Lawyer's Problems in the Registration of Securities, 4 Law \& ConTemp. Prob. 154, I76 (1937). And the State Securities Administrators have done much to improve the situation. Lours Loss AND Edward Cowetr, BLue SKy LAw 230-33 (1958). The question is not whether there should be more coordination, but how it should be achieved without emasculating state securities regulation.
} 
maximum and minimum proposed offering prices and the maximum underwriting discounts have been on file for two full business days. ${ }^{101}$ If the registrant advises the administrator of the date when the federal registration statement is expected to become effective, the administrator must promptly advise the registrant by telephone or telegraph, at the registrant's expense, whether all the conditions are satisfied and whether he then contemplates the institution of a stop order proceeding to deny, suspend, or revoke effectiveness under the Act. ${ }^{102}$ The coordination procedure closely approximates the California procedure as to secondary sales, except that under the Uniform Act (as we shall see later), the administrator has only a very limited power to deny registration to an issue where SEC clearance has been obtained.

The third method of registration is by qualification. The information required to be filed is modeled on schedule A of the Federal Securities Act of r933 and SEC Form S-I. ${ }^{193}$

The administrator may, by rule or order, require as a condition to registration by qualification or by coordination that certain promotion shares be escrowed. .94 $^{10}$ These are limited to shares issued within three years or which are to be issued to a promoter for a consideration substantially different from the public offering price, as well as securities issued to any person for a noncash consideration. The threeyear limitation opens the way for evasion by bankers and promoters who can keep corporate shells with outstanding promotion shares "on ice" for the requisite period. ${ }^{195}$ The administrator may also require that the proceeds from the sale of a registered security be impounded until a specified amount is received. ${ }^{100}$ It is to be noted, however, that the escrow and impound provisions do not require that promotion shares be subordinated to the outside shares in the event of liquidationan ingredient of the $193^{\circ}$ Act-and are not made applicable to securities registered by notification. While the latter exception would not ordinarily be important, situtions may arise where, as a result of a change in the character of the business or otherwise, such registrants are, in fact, issuing promotional securities which should be subordinated.

The crucial section of the new Act is section 306, which specifies the conditions under which the administrator may deny effectiveness to, or suspend, or revoke the effectiveness of a registration statement filed under any one of the three procedures -notification, coordination, or qualification. The Commissioner may issue any such order if he finds that it would be in the public interest to do so and that any

${ }^{101}$ UNIFORM SECURITIES ACr-I956, $\S 303(c)$.

102 Ibid.

${ }^{103}$ Id. $\$ 304(\mathrm{~b})$; Lovis Loss and Edward Cowett, Blue Skx Law 304 (1958).

104 UNIFORM SECURITIES ACT-1956, \$ 305 (g).

${ }^{105}$ The Illinois statute relating to the escrow of promoters' shares reaches back five years. The California statute has no time restriction. Indeed, the escrow provisions of this statute tic the hands of the administrator even more than does the Uniform Sale of Securities Act of 1930. Cf. Unifors SALE or SECURITIES ACT of 1930, § I4, 9 U.L.A. 649 (1942).

${ }^{100}$ UNIFORM SECURITIES ACT- $1956, \S 305(\mathrm{~g})$. 
one of nine other conditions are met. ${ }^{197}$ There is carried over from the $193^{\circ}$ Uniform Act and the 1953 tentative draft the noncontroversial condition that "the offering has worked or tended to work a fraud upon the purchasers or would so operate."198 Added is an important new condition that the offering may be halted if 'it has been or would be made with unreasonable amounts of underwriters' and sellers' discounts, commissions, or other compensation, or promoters' profits or participation, or unreasonable amounts or kinds of options. . .."199

Still absent from the Uniform Act, however, is the "fair, just, and equitable" standard which is to be found in the statutes of at least sixteen states, including all of those which have been the vanguard of securities regulation at the state level. In justification of this crucial omission, we are told: "Administrative flexibility is important in this area, but it must always be balanced against the proper claim of legitimate business to as great a degree of specificity as the public interest will permit." 200 In the "border-line cases which are not quite fraudulent," the regulators may order a prospectus to be used-the oral loophole being preserved-and rely upon full disclosure, as in the Federal Securities Act. ${ }^{201}$ Professor Loss would, thus, scrap some two decades of successful experience in the application of the "fairness" standard in state securities regulation on the ground that it is "too vague."

Unsupported generalizations of a necessity for greater specificity are far less convincing than factual studies such as that of Mr. Albert $\mathrm{K}$. Orschel on the administrative supervision of voluntary plans of corporate reorganization and recapitalization by use of the "fairness" standard. ${ }^{202}$ In contrast with some of the current revelations regarding certain federal administrative agencies, not including the SEC, Mr. Orschel was impressed with the integrity and judgment of the California Commissioner and staff and concluded: "The result is a system in California which more

107 These include: ( 1 ) omissions or misstatements of material facts in the registration statement; (2) willful violation of rules, orders, or conditions imposed in connection with the offering; (3) subsisting administrative stop orders or injunctions applicable to the offering under any other federal or state statute; and (4) illegality of the enterprise or method of business.

${ }^{108}$ UNIForm Sale of Securities Act of 1930, \$ 8(i), 9 U.L.A. 642 (1942); UNIForm Securities ACT $\$ 7-r(3)$ (tentative draft 1953 ).

${ }^{100}$ UnIFORM SECURITIES ACT-1956, $\$ 306(\mathrm{~F})$. For the revelations in congressional hearings held in 1955 and 1956 of enormous bankers' and promoters' profits during the uranium boom, see Hearings, stipra note 90 , at $35-36,579$, passim. Compare the 1946 Statement of Policy of the National Association of Securities Administrators relating to the granting of warrants or stock-purchase options to promoters and underwriters. Nat'l Ass's of Securities Adm'rs, Proceedings 84 (ig46). See I CCH Blue Sky L. ReP. I 457I (1945). For the SEC practice, see Universal Camera Corp., Securities Act Release No. 3076 (1945). A study by the Michigan Securities Commission is reported to have resulted in a finding that underwriters often profit more from the exercise of warrants or stock-purchase options than from the direct commissions received from the sale of securities. Ils. Securmines Dep't ANn. Rep. I9 (I954).

${ }^{200}$ Louis Loss and Edward Cowetr, BLue Sky LAW 327 (1958). For a defense of this omission by Professor Loss-a point which he finds "troublesome"-see NAT'L Ass'N of Securities AdM'rs, ProCEEDINGS $73-76$ (1956). He notes that in all cases of registration by qualification the administrator may require that a prospectus be given to every buyer. UNIFORM SECURITIES ACT-1956, $\$ 304$ (d).

${ }^{201}$ Louis Loss and Edward Cowetr, Blue Sky Law 328 (1958).

202 Orschel, supra note 132. Mr. Orschel, a member of a leading Chicago law firm with a quarter of a century of corporate practice, made this survey while a visiting professor at the Stanford Law School. Unfortunately, Orschel's paper appears to have escaped the attention of the draftsmen of the uniform act. See Lours Loss and Edward Cowetr, Blue Sky Law app. IV (r958). 
effectively protects security holders than have the courts in other states."203 And he adds: "[E]ven if some may bridle at the use of an administrative agency, the annoyances and complaints which any such body of necessity draws to itself seem a reasonable price for a forward looking answer to a difficult legal problem."204

Indeed, lurking behind the movement for uniform legislation in state securities control is the distaste of a segment of the securities industry and the corporate bar for the "paternalistic" blue-sky legislation found in certain midwestern, southern, and western states which have adopted the "fair, just, and equitable" standard. If it is assumed that the states which either have little or no securities regulation will maintain their traditional position-and the tri-partite structure of the new Uniform Act envisages just this result-it is the "fairness" states which will be "leveled" should pressure groups operating under the banner of "promoting uniformity" succeed in displacing existing legislation with the new Act. ${ }^{205}$ It is perhaps this feature of the Act which has caused one enthusiast to proclaim it to be "the greatest invention since the wheel."206 Thus, for the Act to be an outstanding success and accomplish the objective of "uniformity," it must break down the more restrictive legislation of Illinois, Indiana, Michigan, Ohio, and Wisconsin in the Midwest, North Carolina and Texas in the South, and California, Washington, and Oregon in the Far West; ${ }^{207}$ otherwise there is little point to the search for uniformity, except the puristic one of similarity as to terms, definitions, and the like. The experience of these states disproves the notion that the fraud test adopted by the Uniform Act plus limited control over promoters' and bankers' profits will provide a satisfactory base for effective securities regulation. There is a real danger that under the new Act, the courts will hold the fraud test to be applicable only to disclosures in the registration statement (including misstatements and omissions) and not sufficiently broad to proscribe unsound business ventures. ${ }^{208}$ For example, would an alert administrator be able to halt a Tucker issue, as only California did in I947? ${ }^{209}$ Aside from his ability to impose escrow and impound conditions and to

${ }^{203}$ Orschel, supre note 132 , at 236.

204 Id. at 235.

${ }^{205}$ In California, the Committee on Corporations of the Los Angeles Bar Association, after a carcful study of the Act, "has concluded that the Uniform Securities Act in its present form should be changed in a number of significant respects, particularly to provide necessary protection for California investors, and that as so changed the Uniform Securities Act would be a desirable blue sky law for California." Los Angeles Bar Ass'n, Comm. on Corporations, The Uniform Securities Act, 33 L.A. BAn BuLl. 67,88 (1958). For the view of a member of the Corporation Commissioncr's staff, sec Pearce, California Corporate Securities Law vs. Proposed Uniform Securities Law, 9 HAstrngs L.J. I (1957).

${ }^{200}$ Demmler, Progress Toward a Uniform Securities Act: A Result of the Harvard Last School Study, Harv. L.S. Bull., Oct. 1956, p. 16, 22.

${ }^{207}$ Other states using the "fair, just, and equitable" standard are: Alabama, Idaho, Montana, Nebraska, Tennessee, and West Virginia. Kansas, in adopting the new Uniform Act, no longer falls in this category.

${ }^{208}$ But see Statement of Professor Loss, in Nat'L Ass'N of Securities Adm's, Proceedings 73 (1956). This standard is probably unnecessary if the "fair, just, and equitable" test is adopted. The "unsound business" criterion (but not that of "fairness") was inserted in $\$$ ro of the Uniform Sale of Securities Act of r930. Both were excluded from the I953 tentative draft and the Uniform Securitics Act-I956. Cf. UNIFORM SALE OF SECURITIES ACT of 1930, § Io, 9 U.L.A. 644 (I942).

${ }^{200}$ See note Iro supra. 
control promoters' and bankers' profits, the administrator would have no authority to prevent inequitable share structures or impose conditions as to waiver of dividend rights or the right to participate in assets on liquidation in an Old Dominion situation, ${ }^{210}$ not only in case of registration by notification and by coordination, but also in all other circumstances.

Assuming that the fraud standard has some vague content beyond disclosure, it certainly would not embrace inequity and unfairness. As a result, an administrator's. hands would be tied so that he probably could not directly ${ }^{211}$ impose minimum standards relating to security provisions in potentially inequitable situations where there is a public offering of noncumulative preferred shares; ${ }^{212}$ where a provision in a preferred share contract forbidding the corporation to purchase any preferred or common shares when dividends are in arrears does not impose a similar restriction upon subsidiaries; ${ }^{213}$ where a preferred share contingent-voting provision provides: that the voting right shifts upon the passage of four consecutive quarterly dividends, thereby permitting the postponement of a default by staggering the payment of dividends ${ }^{214}$ or where nonvoting common or preferred stock is offered to the public. One other example might be mentioned where the fraud limitation may not afford sufficient protection. A practice has developed in recent years of financing a new venture by selling redeemable, nonconvertible preferred shares to the public for cash, with the insiders taking the common, either for a slight cash investment or as promotion shares. Under this "heads-I-win, tails-you-lose" arrangement, the public investors not only bear the risk of business failure, but can be deprived of a share of the profits if the business succeeds. These examples will serve to indicate that there are countless situations where the administrator needs the power to deny registration on the ground that the proposed issue is not "fair, just, and equitable" to the outside shareholders. It is strange and unfortunate that a major objective of the drive for uniformity seems to be that of eliminating this safeguard from state securities regulation. ${ }^{\mathbf{2 1 5}}$

Moreover, standards of fairness to prevent inequitable arrangements in multisecurities structures have been successfully imposed at the federal level under section 7(c) of the Public Utility Holding Company Act ${ }^{216}$ and section $\mathrm{I} 8$ of the Investment Companies Act. ${ }^{217}$ The stock exchanges view "with disfavor" the listing of non-

s10 Old Dominion Copper Mining and Smelting Company v. Lewisohn, 210 U.S. 206 (rgo8). Again, this is a regression from UNIForM SALE of Securities ACT of I930, \$ I4, 9 U.L.A. 649 (x942).

211 There may be some indirect sanctions. See Statement of Professor Loss, Nat'L Ass'N of SEcurittes Adm'rs, Proceedings 75 (1956).

${ }^{212}$ See Guttman v. Illinois Central R. Co., I89 F.2d 927, 937 (2d Cir. I95I), cert. denied, 342 U.S. 867 (195I) (Frank, Cir. J., suggesting "prophylactic administration action").

${ }^{213}$ Cf. Galdi v. Caribbean Sugar Co., 327 Mass. 402, 99 N.E.2d 69 (I95I).

${ }^{214}$ Sec Benjamin Graham and David L. Dodd, Security Analysis 3 II (3d ed. I95I).

215 See Louis Loss and Edward Cowetr, Blue Sky Law 283, $284,327,328$ (1958).

${ }^{210} 49$ STAT. 815 (x935), $\times 5$ U.S.C. $\$ 77 \mathrm{~g}(\mathrm{c})$ (1952). See Leary, Voting Rights in Preferred Stock Issues Under the Public Utility Holding Company Act of 1935, 27 Tex. L. REv. 749 (1949); Lours Loss, Securities Regulation 263 (I95I).

${ }_{217} 54$ Stat. 8I7 (1940), I5 U.S.C. $\$ 80 a-I 8$ (I952). See Louts Loss, Secunities RegulatroN Ioo (1951). 
voting common stocks or nonvoting preferreds which do not contain adequate contingent voting clauses. ${ }^{218}$ Under these circumstances, it is difficult to understand why it was determined to deny to a state securities administrator a similar discretion with respect to offerings of securities.

(2) Exemptions. In this respect, the new Act follows closely the pattern of previous attempts at uniformity. Among the exempt securities are all those listed on the New York, American, and Midwest stock exchanges, as well as any other security of the same issuer which is of senior or equal rank. ${ }^{210}$

Only "offers" and "sales" of unregistered securities (as distinguished from "issues") are forbidden. ${ }^{220}$ Moreover, the Act enacts the "no-sale" theory, reached by administrative interpretation under the Federal Securities Act of 1933, by specifically excluding from the definition of "offer" and "sale" stock dividends and any act incident to a "class vote by stockholders" pursuant to a charter amendment, reclassification of securities, merger, consolidation, or sale of assets for stock. ${ }^{221}$ Although the draftsmen of the Model Act took the position that a general corporation statute should "enable" and that any "policing must be left to blue-sky statutes," ${ }^{222}$ the draftsmen of the Uniform Securities Act now argue that ${ }^{23}$

this area sufficiently impinges upon the corporation law and other general law of the states so that it seems better not to disturb whatever jurisprudence now applies by subjecting these corporate events to the special statutory sanctions and remedies afforded by the blue sky law.

These fundamental changes are, thus, to be free of administrative regulation at both the state and the federal level. ${ }^{224}$

${ }^{218}$ See Statement of Listing Requirements as to Preferred Stock Voting Rights, N.Y. Stock Exchange, May 4, x940; Policy of Committee on Listing re Voting Rights, Amcrican Stock Exchange, Nov. 12, 1946. The London Stock Exchange has recently taken the position that "ordinary shares carrying no voting rights should not be regarded with favor." 107 L.J. 56x (1957); see Mears, Nonvoting Ordinary Shares, I J. Bus. L. 25 I (1957).

210 Uniford Securities ACT-1956, \$ 402(8). Cf. Uniform SALES of Securities ACt of 1930, $\S 4$ (f), 9 U.L.A. 632 (1942); UNIFORM SECURITIES ACT $\hat{\S}_{3-\mathrm{I}(6)}$ (tentative draft 1953).

${ }_{220}$ UNIFORM SECURITIES ACT-I956, \$\$ 301, 40r(j).

${ }^{221}$ Id. $\$ 40 \mathrm{O}(\mathrm{j})(6)(\mathrm{C})$. The drafting of the new Uniform Securities Act is almost flawless, but a problem is posed by the "class vote" limitation where more than one class of shares is outstanding. Under DeL. Code ANN. tit. 8, $\$ 251$ (1953), on a merger in a two-class situation, a class vote is not mandatory, unless the certificate of incorporation so stipulates. If a class vote were not requircd, would the exchange of securities constitute a "sale" under section 40r? Compare the draftmen's commentary, Louis Loss and Edward Cowett, A Proposed Uniform Securities Act-Final Draft and Commentamy 104 (1956), with Louis Loss AND Edward CowetT, BLuE SkX Law 347 (1958).

222 See text accompanying note 31 supra.

${ }^{223}$ Lours loss and Edward Cowetr, BLUE SKY Law 347 (1958). For the impact of the "no-sale" theory on investor protection under the Federal Securities Act of 1933, see Sargent, A Review of the "No-Sale" Theory of Rule 133, 13 Business Lawyer 78 (1957); Purcell, A Consideration of the No-Sale Theory under the Sectrities Act of 1933, 24 Brookr.yn L. REv. 254 (1958).

${ }^{224}$ The voluminous literature discussing the failure of the courts to curb what Professor E. Merrick Dodd has called the "recapitalization racket" need not be collected here. After carcful study, Professor Dodd favored administrative over judicial supervision. Dodd, Fair and Equitable Recapitalizations, 55 Harv. L. REv. 780, 805, 816 (1942); see also Orschel, supra note 132, at 218 . Two courts have proposed this alternative: Sherman v. Pepin Pickling Co., 230 Minn. 87, 4I N.W.2d 57I (1950); McNulty v. W. \& J. Sloane, 184 Misc. 835,54 N.Y.S.2d 253 (Sup. Ct. 1945 ). The SEC made a detailed study" 
In addition to these compulsory exchanges, the new Act exempts offers to existing security holders of the issuer if no commission or other remuneration (other than a standby commission) is paid for soliciting security holders. ${ }^{225}$ Accordingly, most "voluntary recapitalizations" are, thus, exempted from administrative supervision.

The "isolated sale" problem is solved by exempting any transaction pursuant to an offer directed to not more than ten persons (except institutional investors) during a twelve-month period, if the seller reasonably believes that the buyers are purchasing for investment and no commission is paid for soliciting prospects. The administrator may, by rule or order, withdraw or further condition the exemption or increase or decrease the number of offerees permitted. This broad discretion would appear to permit him either to operate under the ten-offer rule or to adopt a closed-permit procedure, such as that now found in California, or to take some middle course. ${ }^{226}$

In general, in its basic structure, the new Uniform Act is an updated version of the $193^{\circ}$ Act and of the 1953 tentative draft. The most important innovations are the new coordination procedure and the effort to control promoters' and bankers' profits. The Act, however, is not one act, but three acts representing ascending degrees of securities regulation-up to a point. What is conspicuously lacking is a fourth act giving representation to the views of those states which have chosen to make a more serious attempt to control the sale of securities. ${ }^{227}$ The failure to give the same deference to the policies expressed in the statutes of these states as to the statutes of the states with lax blue-sky laws undoubtedly is the basis for the dissatisfaction leading to a withdrawal of approval given the new Act by the North American Securities Administrators. ${ }^{228}$

of the problem and suggested remedial legislation. SEC, op. cit. supra note 133 , pt 7 . The following states exercise some administrative supervision over voluntary reorganizations, mergers, and consolidations: California, Indiana, Oregon, West Virginia, and Wisconsin. And see Cowett, Reorganizations, Consolidations, Mergers and Related Corporate Events, 13 Business LAWYER 418 (1958).

For administrative supervision by the Interstate Commerce Commission of the modification of railroad securities under section $20 \mathrm{~b}$ of the Interstate Commerce Act, 62 STAT. 163 (I948), 49 U.S.C. $\$ 20 \mathrm{~b}$ (1952), see Hand and Cummings, Consensual Securities Modification, 63 HARv. L. REv. 957 (1950); Note, Railroad Modification Act of 1948, I STAN. L. REv. 676 (1949); Comment, Streamlined Capital Readjustment Under Section $20 b$ of the Interstate Commerce Act, 58 YALE L.J. 129I (1949); Hand and Cummings, Funding Arrearages Under Section $20 b$ of the Interstate Commerce Act, 65 Harv. L. Rev. 398 (1952); Wren, Feasibility and Fairness in Section 206 Reorganizations, 52 Colum. L. Rev. 715 (1952).

${ }_{220}$ UNIFORM SECURITIES ACT-I 956, $\$ 402(\mathrm{~b})(\mathrm{II}) . \quad{ }^{226} I d . \$ 402(\mathrm{~b})(9)$.

${ }^{227}$ Guesses as to the gross amount taken from fraudulent stock promotion in the United States range from $\$ 50,000,000$ to $\$ 350,000,000$ a year. A great part of this activity has centered in New York City. See Fratdulent Stock Promotion: A Growth Industry?, Fortune, Aug. 1957, p. 135; Hearings, supra note 90, at $473-7 \mathrm{II}$.

For a recent lament because some of the more financially important states "constituting excellent sales areas, have the so-called "fair, equitable and just' blue-sky laws" and, therefore, are stifling the promotion process (listing California, Florida, Illinois, Michigan, and Texas), see Bruenner and Gilley, Promoters, and their Profits, I3 Business LAwyer 429, 438 (1958). No mention was made of the curious fact that these states continue to enjoy an astonishing economic growth.

${ }^{228}$ See note 6 supra. In 1956 , the NASA, after commending the draftsmen for their "invaluable and outstanding contributions" to the cause of law and administration,

"RESOLVED, That insofar as may be practicable to promote uniformity in legislation, this 


\section{ConcLusion}

This is a large country, and it is to be expected that there will be strong differences of opinion, sectional and otherwise, with respect to corporation and securities legislation. In some states, securities regulation is nonexistent; in others, its admin. istration is so weak that it might as well be abolished; while in a number of states, securities control is of a very high order. One of the virtues of our federal system is that the national government may set a minimum standard of regulation and leave to the states the opportunity to take additional measures if they so desire. ${ }^{220}$ Too often, however, our uniform laws have constituted an amalgamation of common viewpoints in an area and a rejection of a more progressive position, with the result that the proposed statute is inadequate, if not obsolete, soon after its promulgation. This has been particularly true of uniform legislation in the corporate regulation field, and it is unfortunate since there is a wide variety of legislative and administrative experience for any state which would undertake a revision and integration of its corporation and securities laws. We should not allow our quests for uniformity to obscure past achievements or serve as barriers to further progress.

convention assembled approve in the form presented the Uniform Securitics Act, such approval being qualified further as not indicating any opinion regarding any existing state securitics law or the acceptability of the Uniform Securities Act as a substitute therefor, and in no respect requiring any. individual Administrator voting in the affirmative hereon to sponsor, directly or indirectly, the adoption of any such act by the Legislature of his jurisdiction." Nat'L Ass'N of Securumes AdM'rs, Procendings, II2 (1956).

A "clarifying" resolution, adopted at the $x 957$ convention (Ohio abstaining) reads:

"WHEREAS it has been reported in certain publications of general circulation that the North American Securities Administrators at Convention in 1956 approved the proposed Uniform Securitics Act as presented to the convention by Dr. Louis Loss, and,

WHEREAS the Administrators did not approve or endorse said Act, but only endorsed the principle of uniformity in those areas in which the theories of securities laws are approximatcly the same; and

WHEREAS, a clarification of the position of the Administrators appears necessary and ad. visable,

Now, therefore, it is hereby resolved that the resolution as heretofore adopted in 1956 was intended to and did commend the drafters of the proposed Act for the laborious task that they undertook and performed but was not intended to and did not approve or recommend the Uniform Act for adoption in any state." N. Am. Securities Adm'rs, Procezdings 64 (1957). For the interpretation placed on these resolutions by the draftsmen of the Uniform Act, see Lours Loss and Edward Cowett, Blue Sky Law v, 235 (1958).

${ }^{220}$ See Hart, The Relations Between State and Federal Law, 54 Cotum. L. Rev. 489, 495, 539-42 (I954); Strong, Cooperative Federalism, 23 Iowa L. REv. 459, 514-I8 (1938). 